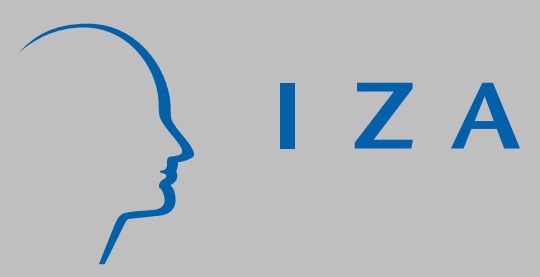

IZA DP No. 709

Delays in Renewal of Labor Contracts: Theory and Evidence

Leif Danziger

Shoshana Neuman

February 2003 


\title{
Delays in Renewal of Labor Contracts: Theory and Evidence
}

\author{
Leif Danziger \\ York University and IZA Bonn \\ Shoshana Neuman \\ Bar-Ilan University, CEPR \\ and IZA Bonn
}

Discussion Paper No. 709
February 2003

IZA

P.O. Box 7240

D-53072 Bonn

Germany

Tel.: +49-228-3894-0

Fax: +49-228-3894-210

Email: iza@iza.org

This Discussion Paper is issued within the framework of IZA's research area Mobility and Flexibility of Labor. Any opinions expressed here are those of the author(s) and not those of the institute. Research disseminated by IZA may include views on policy, but the institute itself takes no institutional policy positions.

The Institute for the Study of Labor (IZA) in Bonn is a local and virtual international research center and a place of communication between science, politics and business. IZA is an independent, nonprofit limited liability company (Gesellschaft mit beschränkter Haftung) supported by the Deutsche Post AG. The center is associated with the University of Bonn and offers a stimulating research environment through its research networks, research support, and visitors and doctoral programs. IZA engages in (i) original and internationally competitive research in all fields of labor economics, (ii) development of policy concepts, and (iii) dissemination of research results and concepts to the interested public. The current research program deals with (1) mobility and flexibility of labor, (2) internationalization of labor markets, (3) welfare state and labor market, (4) labor markets in transition countries, (5) the future of labor, (6) evaluation of labor market policies and projects and (7) general labor economics.

IZA Discussion Papers often represent preliminary work and are circulated to encourage discussion. Citation of such a paper should account for its provisional character. A revised version may be available on the IZA website (www.iza.org) or directly from the author. 
IZA Discussion Paper No. 709

February 2003

\section{ABSTRACT}

\section{Delays in Renewal of Labor Contracts: Theory and Evidence*}

In many countries, an expired labor contract is automatically extended during the often protracted delay before the new contract is signed. Our theoretical model focuses on macroeconomic factors in explaining the delay. It emphasizes the importance of the realized nominal and real shocks, and of the levels of nominal and real uncertainty. The model is tested using Israeli collective wage agreements where long delays are frequent. The empirical findings strongly support the theoretical model. Thus, nominal uncertainty is found to increase the delay, and real uncertainty to decrease the delay, but less in the public than in the private sector.

JEL Classification: J52

Keywords: $\quad$ labor contract, renewal, delay

Corresponding author:

Leif Danziger

Department of Economics

York University

4700 Keele Street

Toronto, Ontario

M3J 1P3

Canada

Tel.: +1 4167365083

Fax: +14167365987

Email: danziger@yorku.ca

\footnotetext{
* The authors are Research Fellows at IZA, where part of this work was carried out. We are grateful to Joseph Deutsch for help with the construction of the data. Leif Danziger thanks the Social Sciences and Humanities Research Council of Canada for financial support.
} 
Delay is preferable to error.

Thomas J eßerson in letter to George Washington, May 16, 1792.

\section{Introduction}

Contemporary labor contracts are usually signed for a ${ }^{-}$xed duration. A typical labor contract speci ${ }^{-}$es its expiration date, and it is rare that a contract has no preset duration or includes a clause permitting reopening or extension of the contract. Nevertheless, the duration of labor contracts is more ${ }^{\circ}$ exible than their rigid wording seems to indicate. In particular, it is common practice that the terms of the old contract are automatically extended during the often protracted holdout period between the stated expiration date of the old contract and the signing of the new one.

In our sample of Israeli labor contracts, $86 \%$ of new contracts are signed after the expiration date of the previous contract. The average delay is 213 days, which is $33 \%$ of the average stated contract duration. For large contract settlements in U. S. industries, Cramton and Tracy (1992) - nd that $47 \%$ of contract renewals take place two or more days after the old contract expired, and, among those contracts, the average holdout from the expiration date of the old contract to the new agreement or the beginning of a strike is 63 days. A mong major Canadian collective bargaining contracts, Gu and K uhn (1998) ${ }^{-}$nd a holdout incidence of $81 \%$, and that the average holdout is 80 days. ${ }^{1}$

Fixed-duration labor contracts play a pivotal role in many models of aggregate ${ }^{\circ}$ uctuations. Starting with Fischer (1977), Phelps and Taylor (1977), and Taylor (1979, 1980),

\footnotetext{
${ }^{1}$ There are also a few contracts with durations shortened by a new contract negotiated and implemented prior to the expiration date of the old one ( $4 \%$ in our sample, and $12 \%$ in Cramton and Tracy's sample). Contract reopenings may be considered negative delays and are the focus of Danziger (1995).

The law in Israel (and similarly in the U. S. and Canada) posits that the conditions of the old contract govern the employment relationship in the period from the expiration date of the old contract until the signing of the new contract or the beginning of a strike/ lockout. This is also true in many other countries, with the major exception of the U. K., where labor contracts are not legally binding. See also Holden (1994).
} 
economists have built macroeconomic models in which staggered multiperiod contracts of - xed duration lead to sluggish adjustment of the aggregate price level and monetary changes to generate real e ${ }^{\text {eects. }}{ }^{2}$ However, variable-duration contracts with state-dependent renewal dates may lead to radically di ßerent conclusions, cf. Caplin and Spulber (1987), who show that even though prices are changed discretely in response to economic developments, the aggregate price level adjusts immediately to monetary shocks, which therefore have no aggregate consequences.

If the delay in contract renewal is endogenous, the eßective duration of the previous contract is state-dependent, notwithstanding the formally stated ' $x$ ed expiration date. Critically, dependency of the delay on macroeconomic variables may seriously weaken the realism and explanatory power of theories in which - xed-duration labor contracts constitute the propagation mechanism for monetary and other macroeconomic shocks. For example, if an in ${ }^{\circ}$ ationary monetary shock reduces delay in contract renewals, e®ectively shortening contract durations, the proportion of new contracts increases with the unanticipated in ${ }^{\circ}$ ation. More contracts are concluded after large than small shocks, and the former are incorporated into new contracts earlier. This mitigates and possibly neutralizes the di Rerential real impacts the shocks would have if contract durations were truly ${ }^{-}$xed.

In view of the above, the purpose of this paper is to examine how the delay in contract renewal depends on aggregate economic variables. Our approach falls within the implicitcontract paradigm and emphasizes the importance of macroeconomic factors, in particular, the driving forces behind the value of money and the real value of a worker's marginal product in the relevant economic branch. We present a four-period economy in which a labor contract between a union and a - rm expires at the end of period two, at which time the parties may either immediately conclude a new labor contract for periods three and

2 See Gray (1978), Dye (1985), Harris and Holmstrom (1987), and Danziger (1988, 1992) for theoretical models of the optimal ${ }^{-}$xed contract duration. The empirical literature on contract durations includes Christo $^{-}$des and Wilton (1983), Ehrenberg et al. (1984), Christo ${ }^{-}$des (1985), Vroman (1989), Murphy (1992), Wallace and Blanco (1991), and Rich and Tracy (2000). Flanagan (1999) surveys the literature concerned with the relationship between collective bargaining systems and macroeconomic performance. 
four, or delay the renewal until the end of period three. The degree of wage indexation is exogenous to the parties negotiating the individual labor contracts. This re $\mathrm{e}^{\circ}$ ects the fact that in Israel the degree of wage indexation is determined by law based on an umbrella agreement between the largest union and the largest federation of employers. ${ }^{3}$

The workers are risk averse and have no access to a capital market. The ${ }^{-} \mathrm{rm}$ is risk neutral, and the discounted expected real payments to a worker in periods three and four equal the discounted expected real value of a worker's marginal product in these periods. If the contract is renewed immediately, neither the price level nor the real value of the marginal product in period four are known at the time of contract renewal. Since the labor contract sets the (partially indexed) nominal wage for period four, the workers become exposed to the nominal uncertainty (that is, the uncertainty in the value of money) in period four, but are fully insured against the real uncertainty (that is, the uncertainty of the real value of their marginal product). Conversely, if the contract renewal is delayed, both the price level and the real value of the marginal product in period four are known at the time of contract renewal. The nominal wage is therefore set so that workers are paid the real value of their marginal product in period four (except for the adjustment for under- or overpayment in period three); the workers are then fully indemni- ed for nominal uncertainty, but fully exposed to real uncertainty. Hence, for given realizations of the shocks in periods two and three, nominal riskiness favors a delay, while real riskiness favors an immediate renewal. ${ }^{4}$

The realizations of the shocks in period two and three determine how much the workers are under- or overpaid given the real value of their marginal product in period three if the contract renewal is delayed. A large under- or overpayment would pull toward immediate

\footnotetext{
${ }^{3}$ The exogenous wage indexation simpli ${ }^{-}$es the model, but is not essential for the results. If the degree of indexation could be freely negotiated, it would depend on the correlation between the price index and the - rm's output and input prices. See Ehrenberg et al. (1984), Card (1986), and Danziger (1988, 1992).

${ }^{4}$ Since a delay shortens the time period during which the provisions of the next contract will be in force, the opposite erects of the two types of riskiness on the decision to delay are similar to the - nding in Danziger (1988). There it was shown that with worker risk aversion, nominal uncertainty tends to shorten, and real uncertainty tends to lengthen contract duration. It is beyond the scope of the present paper to model the joint nature of the decision to delay and the duration of the next contract.
} 
renewal. Accordingly, the ratio of the real wage in period three with a delay to what the real wage would be in a new contract also plays a central role in determining whether contract renewal should be delayed. The optimal timing of contract renewal is shown to follow an $(\mathrm{S} ; \mathrm{S})$ strategy in this ratio: Contract renewal is delayed if the ratio falls between $\mathrm{S}$ and $\mathrm{S}$, and is immediate if the ratio is either less than $\mathrm{S}$ or greater than $\mathrm{S}$.

In order to test our theory, we collected all published collective wage agreements in Israel from 1978 to 1995. This provides us with a sample of 2,103 contracts with a ${ }^{-}$xed termination date and signed at or after the time the previous contract expired. We can match each contract with the relevant macroeconomic variables, making it possible to base our tests directly on the theoretical model. ${ }^{5}$

The empirical ' ndings provide strong support for the theoretical model. Since our data set includes information not only about whether contract renewal is delayed, but also about the length of delay, we can estimate the relationship between the di ßerent parameters and the length of delay. The theory predicts di ßerential impacts of real-uncertainty measures for contracts with ${ }^{-}$rms in the private and public sectors. We therefore ${ }^{-}$rst examine the relationship in the 1,731 private-sector contracts separately, and then the relationship in the full sample of 2,103 private- and public sector contracts where we include interaction terms between the public sector and the explanatory variables.

We use a random-e eects model to estimate the length of delay in the private sector alone and, by adding interaction terms with the public sector, in the private and public sectors together. All the coe \pm cient estimates have the predicted sign and are signi ${ }^{-}$cant. Among the implications of the regression results for the private sector are that in the upward-sloping range, a positive one-standard-deviation nominal shock increases the average delay by 6 days, while a positive one-standard-deviation real shock decreases the average delay by 16 days. In the downward-sloping range, a positive one-standard-deviation nominal shock decreases

\footnotetext{
${ }^{5}$ W e therefore obtain a close integration between the assumption of rational behavior and the labormetrics estimation. See Hamermesh (2000).
} 
the average delay by 26 days, while a positive one-standard-deviation real shock increases the average delay by 69 days. Furthermore, for given realizations of the shocks, a doubling of the variance of the nominal shock would increase the average delay by 22 days, while a doubling of the variance of the real shock would reduce the average delay by 14 days.

Consistent with our theory, the estimates of the coe \pm cients of the interaction terms with the public sector show that real uncertainty shortens the delay less in the public sector than in the private sector, upcoming elections shorten the delay more in the public sector than in the private sector, and unemployment appears to have no signi ${ }^{-}$cant eßect in the public sector in contrast to its negative eßect in the private sector.

We also estimate the e ${ }^{\text {eects }}$ on the likelihood of delay. The evidence is again very clear: whatever increases the delay also increases the likelihood of delay.

W ith its emphasis on macroeconomic factors, our model of optimal contract delay di Rers from previous models. Cramton and Tracy $(1992,1994)$ present and empirically test a bargaining model in which holdouts and strikes are alternative means by which a union can elicit information about a 'rm's willingness to pay. Holdouts entail a loss of productive e \pm ciency, but since holdouts do not involve work stoppages, they are a less costly form for dispute than strikes. The main focus is to determine the relative importance of holdouts in labor disputes, and Cramton and Tracy show that the frequency and length of holdouts decrease with the uncompensated in $^{\circ}$ ation in the old contract, the local unemployment rate, and the demand for the ${ }^{-} \mathrm{rm}$ 's output.

Gu and Kuhn (1998) consider multiple bargaining pairs in an industry. In their model holdouts are also used by unions to elicit information about a ' $r$ 's willingness to pay, but now indirectly by observing settlements between similar bargaining pairs during the holdout period. Gu and Kuhn do not require holdouts to be associated with a loss of productive e \pm ciency, but they also obtain that the frequency and length of holdouts decrease with both the erosion of the real wage in the old contract and the ${ }^{-} \mathrm{rm}^{\prime} \mathrm{s} \mathrm{pro}^{-}$tability. In addition, they show that the incentive to delay increases with the number of similar bargaining pairs and 
that delays are similar for similar bargaining pairs.

It is beyond the scope of this paper to design a test that can distinguish between the di ßerent models. However, we note that since in our model the time of contract renewal is determined by an $(\mathrm{S} ; \mathrm{S})$ strategy in the ratio of the real wage during delay to what the real wage would be in a new contract, the delay is a nonmonotonic function that ${ }^{-}$rst increases and then decreases in this ratio. In the Cramton-Tracy and Gu-Kuhn models the delay always increases in this variable.

\section{The Model}

Consider a four-period economy with nominal and real uncertainty. Thus, the future value of money (de- ned as the inverse of the price level) and the future real value of a worker's marginal product are uncertain.

The value of money in period one is unity, and the value of money in period i relative to the value of money in period $i \mathrm{i} 1(i=2 ; 3 ; 4)$ is $\left(1+{ }^{1}\right)\left(1+x_{i}\right)$, where ${ }^{1}>i 1$ is the trend in the value of money and $x_{i}>i 1$ is a nominal shock. The nominal shocks have zero mean, and are mutually independent and identically distributed with density function $f\left(x_{i}\right)$ on $[\underline{x} ; \boldsymbol{x}]$, where $\underline{x}>\mathrm{i} 1$.

Each worker in a union supplies one unit of labor to $\mathrm{a}^{-} \mathrm{rm}$ in each period. The real value of a worker's marginal product in period $i$ is $A_{i}$, and the real value of the marginal product in period $\mathrm{i}$ relative to that in period $\mathrm{i} i \mathrm{i}$ is $(1+»)\left(1+\mathrm{y}_{\mathrm{i}}\right)$, where $\gg>\mathrm{i} 1$ is the trend in the real value of the marginal product and $y_{i}$ is a real shock. The real shocks have zero mean, and are mutually independent and identically distributed with density function $g\left(y_{i}\right)$ on $[\underline{y} ; z]$, where $\underline{y}>i 1$. Since productivity and demand factors may a Bect both the value of money and the real value of the marginal product, the nominal and real shocks may be correlated.

In period one, the union and the ${ }^{-} \mathrm{rm}$ conclude a two-period labor contract covering periods one and two. The contract sets the nominal wage for period one at $A_{1}$, and the real 
wage is then also $A_{1}$. The nominal wage for period two is determined by a base wage $b$, which is partially indexed to the price level. The degree of indexation is exogenously ${ }^{-}$xed at $\mu, 0<\mu<1$. Hence, the nominal wage in period two is set at bf 1 i $\mu+\mu=\left[\left(1+{ }^{1}\right)\left(1+x_{2}\right)\right] g$, and the real wage is $\left.\mathrm{b}(1 ; \mathrm{i} \mu)\left(1+{ }^{1}\right)\left(1+\mathrm{x}_{2}\right)+\mu\right]$. The base wage is set to make the expected real wage equal to the expected real value of the marginal product, ${ }^{6}$ that is,

$$
\begin{gathered}
\mathrm{b}_{\underline{x}}^{Z_{\bar{x}}}\left[(1 ; \mu)\left(1+{ }^{1}\right)\left(1+x_{2}\right)+\mu\right] f\left(x_{2}\right) d x_{2}=A_{1}(1+») \\
, \quad b=\frac{A_{1}(1+»)}{1+(1 ; \mu)^{1}}:
\end{gathered}
$$

The real wage in period two therefore becomes

$$
\frac{A_{1}(1+»)\left[(1 ; \mu)\left(1+{ }^{1}\right)\left(1+x_{2}\right)+\mu\right]}{1+(1 ; \mu)^{1}}=A_{1}(1+»)\left(1+{ }^{\circ} x_{2}\right)
$$

where $^{\circ}{ }^{\prime} 1 \mathrm{i} \mu=\left[1+(1 ; \mu)^{1}\right]$ is the fraction of the nominal shock transmitted to the real wage.

When the labor contract covering periods one and two expires, the union and the ${ }^{-} \mathrm{rm}$ may choose to conclude a new two-period contract immediately for periods three and four. The new contract is then similar to the expired contract, except that it sets the nominal wage for period three at $A_{3}=\left[\left(1+{ }^{1}\right)^{2}\left(1+x_{2}\right)\left(1+x_{3}\right)\right]$ and the base wage for period four at $A_{3}(1+\gg)=f\left[1+(1 ; \mu)^{1}\right]\left[\left(1+{ }^{1}\right)^{2}\left(1+x_{2}\right)\left(1+x_{3}\right)\right] g$. The real wage in period three is therefore $A_{3}$, which is the real value of the marginal product in period three. The realized real wage in period four becomes $A_{3}(1+\gg)\left(1+{ }^{\circ} x_{4}\right)$, and the expected real wage in period four is $A_{3}(1+\gg)$, which is the expected real value of the marginal product in period four.

\footnotetext{
${ }^{6}$ It is only for simplicity that the model assumes that the real wage in period one and the expected real wage in period two equals the real value of the marginal product in period one and the expected real value of the marginal product in period two, respectively. More generally, it could be assumed that the discounted expected value of the real wages in the two periods equals a fraction (representing the union's relative bargaining strength) of the discounted expected real value of the marginal products from these periods. This would complicate the analysis without changing the central results.
} 
Alternatively, the union and the - $r$ may delay contract renewal to period four, in which case the provisions of the old contract are automatically extended to cover period three. ${ }^{7}$ The relative change in the base wage between periods two and three is similar to that between periods one and two, and the base wage is again partially indexed to the price level. Accordingly, the nominal wage in period three is set at $A_{1}(1+\gg)^{2} f 1 ; \mu+$ $\mu=\left\{\left(1+{ }^{1}\right)\left(1+x_{2}\right)\right] \operatorname{gf} 1 ; \mu+\mu=\left[\left(1+{ }^{1}\right)\left(1+x_{3}\right)\right] g\left[1+(1 ; \mu)^{1}\right]^{i}{ }^{2}$, and the real wage becomes $A_{1}(1+\gg)^{2}\left(1+{ }^{\circ} x_{2}\right)\left(1+{ }^{\circ} x_{3}\right)$. Let

$$
z^{\prime} \frac{\left(1+{ }^{\circ} x_{2}\right)\left(1+{ }^{\circ} x_{3}\right)}{\left(1+y_{2}\right)\left(1+y_{3}\right)}
$$

denote the ratio of the real wage with a delay to what the real wage would be with a new contract. The real wage in period three can then be written as $A_{3} z$. The real under- or overpayment to the worker during the extension is $A_{3}(1 ; z)$.

The delayed contract, when it is eventually concluded in period four, is made retroactive to period three. As the price level and the real value of the marginal product in period four are now known, the wage in period four is set so that the real wage is equal to the real value of the marginal product plus a retroactive payment representing the current value of the real under- or overpayment to a worker during the extension of the previous contract. ${ }^{8}$ Let $r>\mathrm{i} 1$ denote the real interest rate. Accordingly, if the conclusion of the new contract is delayed, the real wage in period four is $A_{4}+A_{3}\left(1_{i} z\right)(1+r)=A_{3}\left[(1+»)\left(1+y_{4}\right)+\left(1_{i} z\right)(1+r)\right]^{9}$

A worker cannot borrow or lend. He is risk averse and his utility in each period is a logarithmic function of his real income during that period. The expected utility from periods one and two covered by the ${ }^{-}$rst contract is independent of the time at which the

\footnotetext{
${ }^{7}$ As mentioned in footnote 1 , this is the legal practice in many countries.

${ }^{8}$ T he model thus captures that new contracts are typically backdated and contain a retroactive payment. Since the discounted expected real pro ${ }^{-}$ts per worker are $\left.A_{3}[1+(1+\gg) \neq 1+r)\right]$ whether there is a delay or not, the retroactive payment has the valuable implication that the delay decision is of no concern to the - rm.

${ }^{9}$ It is assumed that $\left.(1+\gg)(1+\underline{y}) \neq 1+r\right)+1>\left[\left(1+{ }^{\circ} \mathrm{x}\right) \neq(1+\underline{y})\right]^{2}$, so that the real wage is positive.
} 
next contract is concluded. The expected utility from periods three and four, however, depends on when the new contract is concluded. Let $1 / 2>$; 1 denote a worker's discount rate. On the one hand, with an immediate renewal, the discounted expected utility from periods three and four is

$$
\begin{aligned}
& \left.\ln A_{3}+\frac{1}{1+1 / 2}{ }^{Z} \underline{x}_{\operatorname{x}} \ln \left[A_{3}(1+»)\left(1+{ }^{\circ} x_{4}\right)\right] f\left(x_{4}\right) d x_{4}\right) \\
= & \ln A_{3}+\frac{1}{1+1 / 2} \ln \left[A_{3}(1+»)\right]+{ }_{\underline{x}} \ln \left(1+{ }^{\circ} x_{4}\right) f\left(x_{4}\right) d x_{4}:
\end{aligned}
$$

On the other hand, with a delayed renewal, the discounted expected utility from periods three and four is

$$
\begin{aligned}
& \ln \left(A_{3} z\right)+\frac{1}{1+1 / 2}\left(\underline{y}_{\bar{y}} \operatorname{lnf} A_{3}\left[(1+»)\left(1+y_{4}\right)+(1 ; z)(1+r)\right] \operatorname{lgg}\left(y_{4}\right) d y_{4}, \quad\right) \\
= & \ln \left(A_{3} z\right)+\frac{1}{1+1 / 2} \ln \left[A_{3}(1+\nu)\right]+{ }_{\underline{y}}^{z_{y}} \ln 1+y_{4}+\frac{(1 ; z)(1+r)}{1+»} g\left(y_{4}\right) d y_{4}:
\end{aligned}
$$

The bene ${ }^{-} t$ from a delay depends on $z$ and is obtained by subtracting the discounted expected utility from periods three and four of a contract which is concluded immediately from the discounted expected utility from periods three and four of a contract with delayed renewal,

$B(z)^{\prime} \ln z+\frac{1}{1+1 / 2} \underline{y}^{z} \ln 1+y_{4}+\frac{(1 ; z)(1+r)}{1+»}^{\#} g\left(y_{4}\right) d y_{4} i \frac{1}{1+1 / 2} \underline{x}^{z} \ln \left(1+{ }^{\circ} x_{4}\right) f\left(x_{4}\right) d x_{4}:$

Since the utility function is logarithmic, the bene ${ }^{-} t$ from a delay is independent of a possible correlation between nominal and real shocks. Furthermore, the nature of indexation implies that the size of the nominal shocks and the fraction ${ }^{\circ}$ of these shocks transmitted to the real wage enter only multiplicatively into the bene ${ }^{-} t$ from a delay $\left\{\right.$ as ${ }^{\circ} x_{2}$ and ${ }^{\circ} x_{3}$ in $z$, and as ${ }^{\circ} x_{4}$. Accordingly, a change in the nominal shocks by a factor of,$>0$ together with a simultaneous change in the degree of indexation or in the trend in the value of money such that ${ }^{\circ}$ changes by a factor of $1=$, would have no impact on $B(z)$.

The ${ }^{-} \mathrm{rm}$ is risk neutral and since its discounted expected real pro ${ }^{-}$ts per worker are the same with and without a delay, it agrees that the timing of the contract renewal is chosen 
to maximize a worker's discounted expected utility. Accordingly, the contract renewal is delayed if $\mathrm{B}(\mathrm{z})>0$; the contract is immediately renewed if $\mathrm{B}(\mathrm{z})<0$; and the contract renewal is either delayed or immediate if $B(z)=0$.

The bene ${ }^{-} t$ from a delay is a strictly concave function of $z$ with an internal maximum at $z=z^{x} d e^{-}$ned by

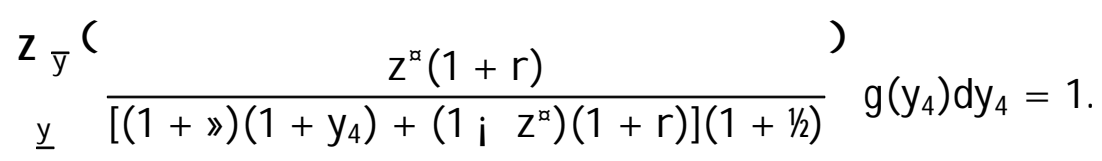

This re ects that if $z<z^{\ltimes}$, larger nominal shocks or smaller real shocks in periods three and four bring the real wage in period three with a delay closer to maximizing the discounted expected utility with a delay; if $z>z^{\natural}$, the opposite holds.

It is assumed that the real uncertainty is not so extreme that it would never be optimal to delay the contract renewal, $B\left(z^{\mathbb{a}}\right)>0$. A lso, it is assumed that the shocks are su \pm ciently dispersed that there are shocks for which $z<z^{\infty}$ and it is optimal to immediately renew the contract, $\mathrm{B} f\left[\left(1+{ }^{\circ} \underline{x}\right)=(1+\bar{y})\right]^{2} \mathrm{~g}<0$, as well as shocks for which $\mathrm{z}>\mathrm{z}^{\mathrm{\alpha}}$ and it is optimal to immediately renew the contract, $B f\left[\left(1+{ }^{\circ} \mathrm{X}\right)=(1+\underline{y})\right]^{2} g>0$. The optimal timing of contract renewal can then be described as a two-sided $(\mathrm{s} ; \mathrm{S})$ strategy in $\mathrm{z}$, where the lower and upper critical values of $z$, denoted by $s$ and $S$, are unique and de ned by $B(s)=B(S)=0$, $\mathrm{S}<\mathrm{S}$ : For a given realization of shocks in periods two and three, the renewal is delayed if $z 2(s ; S)$, is immediate if $z Z(s ; S)$, and is either delayed or immediate if $z=s$ or $z=S$. Figure 1 shows the bene ${ }^{-} t$ from delay and illustrates the choice between delay and immediate renewal. The value of $\mathrm{z}$ is measured on the horizontal axis and $\mathrm{B}(\mathrm{z})$ is measured on the vertical axis. ${ }^{10}$

10 In the special case of no real uncertainty and $1 / 2=0$, then $B(z)$ is symmetric around $z^{\alpha}=\frac{1}{2}[1+(1+$ $\gg)=(1+r)]$ and $\left.B\left(z^{\alpha}\right)=\operatorname{lnf}(2+r+\gg)^{2} \neq 4(1+\gg)(1+r)\right] g i \quad R_{\bar{x}} \ln \left(1+{ }^{\circ} x_{4}\right) f\left(x_{4}\right) d x_{4}$. A worker is then indi Rerent between receiving the real wage $z^{\mathfrak{\alpha}} i$ Á, $A>0$, in period three and the expected real wage $z^{\mathfrak{\alpha}}+\dot{A}$ in period four, and vice versa. Since the left-hand side of eq. (1) increases with $z^{\alpha}$ and is a convex function of $y_{4}$, real uncertainty leads to a decrease in $z^{\not \alpha}$. 


\section{The Bene ${ }^{-} t$ from a Delay and the Critical Values of z: Comparative Statics}

It has been shown that the bene ${ }^{-} t$ from delay depends on the realized shocks as manifested in $z$ : the bene $t$ increases with $z$ if $z<z^{a}$ and decreases with $z$ if $z>z^{a}$. The bene $t$ therefore increases with the nominal shocks if $z<z^{\not a}$ and decreases with the nominal shocks if $z>z^{\not}$, while the real shocks have the opposite eßect. We now examine how the parameters a Rect the bene ${ }^{-} t$ for a given $z$, and also study the eßects of the parameters on the upper and lower critical values of $z$.

The nominal parameters $\{$ the trend in the value of money, the level of the nominal uncertainty, and the degree of indexation $\{$ have no eßect on the discounted expected utility from a contract with delayed renewal, for a given $z$. The reason is that a worker in period three receives the real wage $A_{3} z$, which is given since $A_{3}$ and $z$ are given; in period four he receives a real wage equaling the real value of the marginal product plus retroactive pay for period three, and therefore independent of the change in the value of money from period three to four. Thus, delayed renewal protects the worker from any real eßects of anticipated and unanticipated changes in the value of money from period three to four.

However, the same nominal parameters a rect the discounted expected utility if the contract is renewed immediately in period three. In this case, an increase in the nominal uncertainty increases the uncertainty of the real wage in period four, which reduces the riskaverse worker's discounted expected utility. The magnitude of the impact of the nominal uncertainty depends on the fraction ${ }^{\circ}$ of period four's nominal shock transmitted to the real wage. Since ${ }^{\circ}$ increases with ${ }^{1}$ and decreases with $\mu$, an increase in ${ }^{1}$ is equivalent to an increase in uncertainty, while an increase in $\mu$ is equivalent to a decrease in uncertainty. So for a given $z$, both the trend in the value of money and the nominal uncertainty lead to a decrease in the discounted expected utility, increasing the bene ${ }^{-} t$ from a delay, while the degree of indexation increases the discounted expected utility, decreasing the bene- $t$ from a delay. As is clear from Figure 1, a larger trend in the value of money and more nominal 
uncertainty lead to a decrease in $\mathrm{S}$ and an increase in $\mathrm{S}$, thereby widening the range of $\mathrm{Z}^{\prime} \mathrm{S}$ for which the contract renewal is delayed; more indexation leads to an increase in $\mathrm{s}$ and a decrease in $S$, thereby narrowing the range of $Z^{\prime} s$ for which the contract renewal is delayed.

Turning to the trend in the real value of the marginal product, this has no e®ect on the third period's wage in either contract for a given $A_{3},{ }^{11}$ but does a Rect the fourth period's wage in both contracts. If the contract is renewed in period three, the fourth period's wage is proportional to $1+»$. If the renewal is delayed and $z=1$ (so that there is no retroactive pay in period four), the fourth period's wage is also proportional to $1+»$. In this case the real wage in period three is the same irrespective of whether or not the contract renewal is delayed. The bene ${ }^{-} t$ from a delay is therefore independent of $»$, and $B(1)$ does not change with ».

If the renewal is delayed and $z>1$, the real wage in the third period is greater and the expected real wage in the fourth period is less than if the contract is renewed in period three. Due to the gains from a smoother intertemporal consumption, an increase in » is therefore more bene $e^{-}$cial if the contract renewal is delayed. If the renewal is delayed and $z<1$, the opposite is true. Consequently, » a Rects the bene ${ }^{-} t$ from a delay positively for $z>1$ and negatively for $z<1$. It follows that $d s=d » z 0$ as $s \lesseqgtr 1$ and $d S=d » \gtreqless 0$ as $S \geq 1 .{ }^{12}$

Real uncertainty has no e ${ }^{\text {Rect }}$ on the discounted expected utility from a contract concluded in period three, since the expected real wage in period four then equals the expected real value of worker's marginal product and is independent of the real uncertainty. The worker is fully insured against real uncertainty in period four. However, uncertainty reduces the expected utility from a delayed contract, since the real wage in period four becomes exposed to the real uncertainty. Accordingly, an increase in real uncertainty decreases the

\footnotetext{
11 We ignore the eßects of » on the wages through $A_{3}$, since the wages in the third and fourth period are proportional to $A_{3}$ irrespective of whether the contract renewal is delayed.

12 The e Rect on the range of $z$-values for which the contract renewal is delayed depends on the values of $S$ and $S$ relative to unity: $A$ bigger trend in productivity widens the range of $z$ values for which the contract renewal is delayed if $1 \cdot \mathrm{S}<\mathrm{S}$; narrows the range if $\mathrm{S}<\mathrm{S} \cdot 1$; and moves the range to the right if $\mathrm{s}<1<\mathrm{S}$.
} 
bene ${ }^{-} t$ from a delay. Hence, $s$ increases and $S$ decreases, leading to a narrower range of $z^{\prime} s$ for which the contract renewal is delayed.

Finally, the eßect of the real interest rate works through the value of the retroactive pay in period four of a delayed contract. If the retroactive pay is positive (negative), the real wage in period four increases (decreases) with the real interest rate. It follows that $r$ has the opposite erect of » on the bene ${ }^{-} t$ of a delay. So, if $z=1$, the bene ${ }^{-} t$ from a delay is independent of $r$; if $z>1$, it decreases with $r$; and if $z<1$, it increases with $r$. Accordingly,

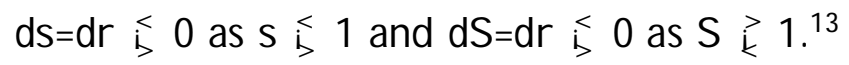

The comparative-static relationships are summarized in Table 1.

\section{The Israeli Economy 1978-1995}

The development of some of the major macroeconomic variables in Israel during 1978-1995 is summarized in Table 2. During this time span, the Israeli economy experiences two distinct periods of in ${ }^{\circ}$ ation: The annual in ${ }^{\circ}$ ation rate climbs from $48.1 \%$ in 1978 to about $800 \%$ in M ay 1985 (with a highly variable monthly in ${ }^{\circ}$ ation); thereafter, the stabilization program, enacted in M ay 1985, reduces the in ${ }^{\circ}$ ation rate to $19.7 \%$ in 1986 and further to $8.1 \%$ in 1995. The average annual in ${ }^{\circ}$ ation rate for the entire period is around $60 \%$. This is illustrated in Chart 1.

The growth rate of per-capita GDP exhibits no clear trend. The growth rate varies between an annual minimum of $\{0.56 \%$ in 1989, and an annual maximum of $10.6 \%$ in 1991 (caused by mass immigration that started in September 1989 and the 0 slo accords). This is illustrated in Chart 2. The annual real interest rate exhibits a hump-shaped pattern, similar to the pattern of the $\mathrm{in}^{\circ}$ ation rate. The real interest rate is on average $19.9 \%$, and varies between a minimum of $\{11.4 \%$ in 1979 and a maximum of $90.6 \%$ in 1985 . The unemployment rate rises from an annual average of about 3\% in 1978-79 to a peak of $11.2 \%$ in 1992 (due

\footnotetext{
${ }^{13} \mathrm{~A}$ higher real interest rate narrows the range of $\mathrm{Z}^{\prime} \mathrm{s}$ for which the contract renewal is delayed if $1 \cdot \mathrm{s}<\mathrm{S}$; widens the range if $\mathrm{s}<\mathrm{S} \cdot 1$; and moves the range to the left $\mathrm{s}<1<\mathrm{S}$.
} 
to the mass immigration during 1989-1992). The trend then changes and unemployment decreases during 1993-1995. The number of work days lost due to strikes shows no apparent trend. The average is 574 days per thousand workers, ranging from a minimum of 63 days in 1991 to a maximum of 1,552 days in 1982.

\section{The Sample of Labor Contracts}

Israeli employers are required to report all collective bargaining agreements to the M inistry of Labour and Social A Rairs. The main characteristics of the labor contracts are subsequently published in the Ministry's Monthly Bulletin, which identi- es the parties to the contract, the contract's starting date (assumed to be the expiration date of the previous one), the signing date, the termination date, the economic branch, and important contract provisions, such as wages, vacations, and pensions. Our sample includes all published contracts dealing with wage provisions signed between 1978 and 1995 with a ${ }^{-}$xed termination date. ${ }^{14}$ All the contracts, whether in the private or public sector, result from negotiation by the parties and not from legislative intervention. There are 92 ( $4 \%$ of total) new contracts signed before the previous contracts terminated and therefore exhibiting a negative delay. These contracts are excluded, leaving a sample of 2,103 contracts which are used in the empirical study. They stem from 711 di ßerent ' $r m s$ (including public-sector employers), since $325^{\circ}$ rms enter the sample more than once as they conclude several agreements over the years. As a result, our sample is an unbalanced panel data set. We distinguish between contracts in the private and public sectors. ${ }^{15}$ Table 3 shows the distribution of the contracts by sector and economic branch. ${ }^{16}$ A bout $82 \%$ of the contracts are in the private sector (1,731 contracts) and $18 \%$

\footnotetext{
14 In the beginning of the 1980s the unionization rate was about 85\%. In 1995 health insurance was separated from union membership, causing a sharp fall in the unionization rate to about $50 \%$ as well as radical changes in labor relations (Cohen et al., 2001). We ther efore decided not to include contracts signed after 1995 in the sample.

15 The public sector includes municipalities, universities, and most hospitals, among others.

16 Firms in the public-services branch are not necessarily in the public sector. For example, private schools and private hospitals belong to the public-services branch but not to the public sector.
} 
are in the public sector (372 contracts). Concerning the economic branches, over half of the contracts are in Manufacturing, over a quarter in Private Services, about $9 \%$ are in Public Services, while only $4.4 \%$ are in Commerce and $2.2 \%$ are in Banking Institutions.

The delay in contract renewal is the di ßerence between the signing date of the new contract and the expiry date of the old one. Table 4 provides summary statistics of the delays in contract renewals and contract durations. Only 10\% of the contracts are signed on time and only another $1.9 \%$ are signed with a delay of at most one week. The average delay is 213 days. The delay varies greatly, from zero to 1,529 days with a standard deviation of 207 days. Chart 3 shows the distribution of delays. The private sector has an average delay of 194 days, while the public sector has a longer average delay of 304 days. In the public sector the delays are also more dispersed. So the public sector is characterized by longer and more dispersed delays in contract renewals.

We have no information about whether a contract settlement is reached following the onset of a strike, or when such strike begins. Our measure of delay therefore includes the length of any strike prior to the signing of the new contract. However, such strikes are rare since the average yearly number of strikes in all of the Israeli economy during 1983-1992 is 127 and only 13\% of all strikes are caused by the inability of the parties to reach a new contract (Bar-Zuri, 1994).

The duration of a new contract includes the delay and is therefore calculated as the di ßerence between the termination dates of the new and old contracts. The average duration of a labor contract is 649 days, which is about three times the average delay. There are two cluster points: at one year ( $21 \%$ of the contracts) and at two years ( $52 \%$ of the contracts). Only $10 \%$ of the contracts exceed two years, and a mere 3\% exceed three years. Contracts in the public sector are longer than in the private sector: in the private sector the average duration is 629 days, while in the public sector the average duration is 747 days. A mong the private-sector contracts, $8 \%$ are signed for more than two years and $2 \%$ for more than three years. The corresponding percentages for the public sector are more than double: $19 \%$ for 
more than two years and $11 \%$ for more than three years.

\section{The Empirical Implementation}

In order to test the model's predictions for the delay in contract renewals, we take a secondorder Taylor approximation of the bene ${ }^{-} \mathrm{B}(\mathrm{z})$ from delaying the new contract at $\left(\mathrm{x}_{4} ; \mathrm{y}_{4}\right)=$ $(0 ; 0)$. This yields

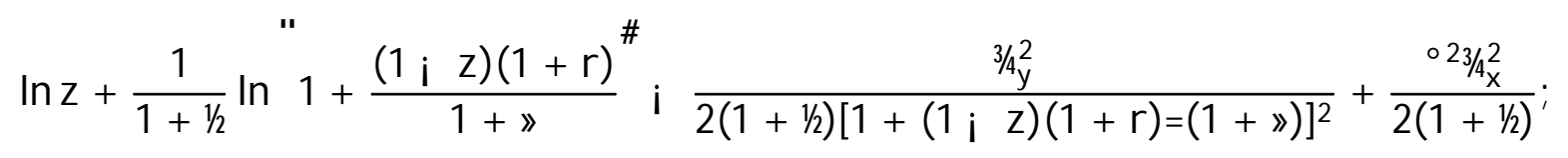

where $3 / 2$ is the variance of the nominal shock, and $3 / \frac{2}{y}$ is the variance of the real shock. Since $(1 ; z)(1+r)=(1+»)$ is small, we further approximate the bene ${ }^{-} t$ from a delay by

$$
B(z)^{\prime} \ln z+\frac{1}{1+1 / 2} \ln 1+\frac{(1 \mathrm{i} z)(1+r)}{1+»} \text { i } \frac{3 / 4}{2(1+1 / 4}+\frac{{ }^{\circ 23 / 2}}{2(1+1 / 4}:
$$

In the empirical model, we interpret $B(z)^{-}$rst as the delay and afterwards as the likelihood of delay.

All variables are measured at the time the old contract expires, except the degree of indexation. The logic is that the decision about a possible delay in contract renewal is based on the data available at the point at which the old contract expires.

We now de ${ }^{-}$ne and describe each of the variables used in the empirical analysis. Table 5 presents the means and standard deviations together with their minimum and maximum values. ${ }^{17}$

The rate of change in the actual value of money from month $\mathrm{m} i 1$ to month $\mathrm{m}$ is ${ }^{1} \mathrm{~m}$ ' $\left(p_{m_{i} 1}=p_{m}\right) ; 1$, where $p_{m_{i} 1}$ and $p_{m}$ are the consumer price indexes in months $m_{i} 1$ and $m^{18}$ We use $A R(6)$ to estimate the trend in the value of money from month $m_{i} 1$ to month $m$,

17 The values are calculated over the 2,103 contracts. The values of the macro variables calculated over the years 1978-1995 are similar.

18 The monthly consumer price index is published in the M onthly Bulletin of Statistics. 
${ }^{r_{\mathrm{m}}} \cdot{ }^{19}$ The estimated average ${ }^{{ }^{2}} \mathrm{~m}$ is $\mathrm{i} 0: 0385$, with a standard deviation of 0.0384 .

The estimated nominal shock is the di ßerence between the rate of change in the actual value of money and the estimated trend in the value of money, $\mathrm{x}_{\mathrm{m}}{ }^{\prime}{ }^{1} \mathrm{~m} \mathrm{i}{ }^{{ }^{n}}{ }_{\mathrm{m}}$. The standard deviation of the shock is 0.0238 , and the shock ranges from -0.1185 to 0.1385 . We use the (moving-average) variance of the shocks in the previous six months as an estimate of the expected variance of the shock in month $\mathrm{m}$. The expected variance is, on average, 6:8E $\{4$ and ranges from 2:9E $\{6$ to $7: 5 E$ $\{3$.

Since there is no published data on the real value of the marginal product, we instead use the per-capita GDP in the empirical analysis on the assumption that the real value of the marginal product is proportional to the per-capita GDP. The GDP is published annually for each economic branch, ${ }^{20}$ and we calculate the rate of change in the actual per-capita GDP in a branch for each month $m$ in year a as " $m=\left[\left(G D P_{a}=G D P_{a_{1} 1}\right) i 1\right]^{1=12}$, where GDPa and GDP $a_{i} 1$ are the per-capita GDP in the branch in year $a_{i} 1$ and $a$. We use AR(2) to estimate the trend in branch per-capita GDP from year $a_{i} 1$ to year $a_{1} \hat{~}_{a}{ }^{21}$ and calculate the trend in the branch per-capita GDP for each month $m$ in year a as ${\nu_{m}}_{m}{\aleph_{a}=12}^{1=}$. The average branch-speci ${ }^{-} \mathrm{c}$ per-capita monthly GDP trend ranges from $0.11 \%$ in Commerce to $0.42 \%$ in Private Services.

The estimated real shock in a branch in a month in year a is the deviation of the estimated trend in the branch per-capita GDP from the rate of change in actual branch per-capita GDP, $\left.y_{m}{ }^{\prime} \nu_{m} \mathbf{i}\right\rangle_{m}$. As an estimate of the expected variance of the shock in each month of the year, $3 / \mathrm{y}_{\mathrm{m}}$, we use the (moving-average) variance of the shocks in the months of the previous

\footnotetext{
19 We also tried to estimate the trend in the value of money by six-month moving arithmetic or geometric averages, which were very similar. The estimations were repeated using AR(12). W hile the estimates are somewhat di Rerent, they lead to similar conclusions in the regression analyses.

In addition, we experimented with six- and twelve-months partly backward- and partly forward-looking estimates. These perform less well in the regression analyses.

20 The annual branch GDP is published in the Monthly Bulletin of Statistics.

${ }^{21}$ Similarly to estimating the trend in the value of money, we also tried moving arithmetic and geometric versions, which leads to similar estimates. Using AR (3) to estimate the productivity trend does not change the signs and signi ${ }^{-}$cance of the coe \pm cients in the delay regressions.
} 
two years. The ranking of the branches in terms of increasing uncertainty of their real shocks is: Public Services, B anking Institutions, Commerce, Private Services and M anufacturing.

Taking an average over all 2,103 contracts, the monthly estimate of the trend in the branch per-capita GDP, $\hat{}_{m}$, ranges from $\{2.24 \%$ to $5.27 \%$, with an average monthly trend for $1978-1995$ of $0.32 \%$. The standard deviation of the monthly real shocks is 0.0263 , and the shock size ranges from -0.0306 to 0.0780 . The expected variance of the monthly real shocks, is on average 2:3E $\left\{4\right.$ and ranges from 5:9E $\left\{9\right.$ to $2: 6 \mathrm{E}\left\{3 .{ }^{22}\right.$

The wage indexation rules in Israel are determined by agreements negotiated between the Histadrut (the largest union) and the Coordinating Bureau of Economic Organizations (the largest federation of employers). Subsequently, the K nesset (the Israeli Parliament) extends the rules to cover all workers in the economy, and the wage indexation is therefore exogenous to the parties concluding a labor contract. The typical indexation agreement is complicated since the degree of indexation depends on the in ${ }^{\circ}$ ation rate. Empirically, the degree of indexation is measured as the rate of change in the wage during the contract period due to indexation divided by the rate of change in the consumer price index over the same period. ${ }^{23}$ The average degree of indexation is 0.5888 , implying that indexation on average compensates the workers for $58.9 \%$ of the decrease in their real wages due to in ${ }^{\circ}$ ation.

The annual real interest rate is published by the Bank of Israel. ${ }^{24} \quad$ If $r_{a}$ denotes the real interest rate in year $a$, we calculate the monthly real interest rate for each month in year a as $r_{m}=\left(1+r_{a}\right)^{1=12} ; \quad 1$. The average monthly real interest rate is $1.53 \%$ and ranges from $-1 \%$ to $5.4 \%$.

${ }^{22}$ We have also experimented with using economy-wide GDP productivity measures, which have the advantage that the GDP - gures are available on a quarterly basis. Since branch-productivity measures are more relevant for the delay decision in a given branch, the regression results using economy-wide GDP productivity measures are less satisfactory.

${ }^{23}$ The degree of indexation in a contract is therefore measured on average, which is the appropriate measure for determining the real wage during a delay. The marginal degree of indexation is preferable for determining the impact of the uncertain future value of money, but we assume that the degree of indexation in a contract is constant so that the average and marginal degrees of indexation are identical.

24 See Bank of Israel Annual Report. 
We calculate the fraction of a nominal shock which is transmitted to the real wage as ${ }_{\mathrm{m}}^{\circ}=(1 ; \mu)\left(1+{ }^{n_{m}}\right)\left[1+(1 ; \mu)^{n_{m}}\right]$ for a contract with starting date in month $\mathrm{m}$. The average ${ }^{\circ} \mathrm{m}$ is 0.4035 , and it varies from zero (when $\mu=1$ ) to 0.9663 . The value of $z$ for $a$ contract with starting date in month $\mathrm{m}$ is obtained as $\mathrm{z}=\left(1+{ }_{\mathrm{m}}^{\circ} \mathrm{x}_{\mathrm{m}}\right)=\left(1+\mathrm{y}_{\mathrm{m}}\right)$. The average $z$ is 0.9916 with a standard deviation of 0.0254 , indicating that the distribution of $z$ is very concentrated. As the empirical measure of $z^{\infty}$ we use the value of $z$ which maximizes $B(z)$, $z^{\not x}=\left(2+\hat{\nu}_{m}+r_{m}\right)=\left[2\left(1+r_{m}\right)\right] .^{25}$ The average $z^{\not}$ is 0.9916 , and $48 \%$ of the contracts have $z<z^{\mathbb{a}}$ with the remaining $52 \%$ having $z>z^{a}$.

Upcoming elections to the $\mathrm{K}$ nesset is an additional indicator of increased real uncertainty as the election of a new government may presage important economic and political changes. This is of particular importance for workers employed in the public sector where budgets are determined by a political process; upcoming elections are therefore accompanied by more real uncertainty for workers in the public sector than for workers in the private sector.

We use a dummy variable equal to one if the previous contract expires less than one year before elections, and equal to zero otherwise. In our sample, $22.4 \%$ of the previous contracts expire less than one year before elections. Similarly to the variance of the real shocks, we expect upcoming elections to have a negative eßect on the delay.

We also use the annual unemployment rate when the previous contract expired as an explanatory variable. ${ }^{26}$ This is a traditional measure of labor-market tightness. ${ }^{27}$ Since a high unemployment rate is likely to increase a worker's risk of being ' red and might also lead to policy interventions, it is associated with more real uncertainty. In our sample, the average unemployment rate when the previous contract expired is $7.05 \%$, with a minimum of $2.88 \%$ and a maximum of $11.8 \%$.

\footnotetext{
25 For simplicity, we set $1 / 2=0$.

26 The annual unemployment rate, published in the A nnual Statistical A bstracts of Israel, is the average of the estimated quarterly unemployment rates based on the Labor Force Surveys.

27 See, for example, Vroman (1989) and Murphy (1992).
} 
To account for di Rerences in the constraints of the economic environment and the laborrelations culture, we include dummy variables to capture the eßects of the -ve economic branches in the economy. ${ }^{28}$

We separate between the private and public sectors as we expect systematic di ßerences. The public sector, being less exposed to the vicissitudes of market forces than the private sector, should react less to real uncertainty. Similarly, it should be less a Rected by the unemployment rate. At the same time, upcoming elections likely indicates more real uncertainty for public- than private-sector workers, and we therefore surmise that the e Rect may be more pronounced in the public sector. ${ }^{29}$

\section{Econometric Estimation}

To estimate our theoretical model, we run cross-sectional time-series regressions of the following type:

$$
\operatorname{DELAY}{ }_{\mathrm{tj}}={ }^{\circledR}+{ }^{-} X_{\mathrm{t}}+\Psi_{\mathrm{j}}+\dot{A} W_{\mathrm{tj}}+{ }^{2} \mathrm{tj}
$$

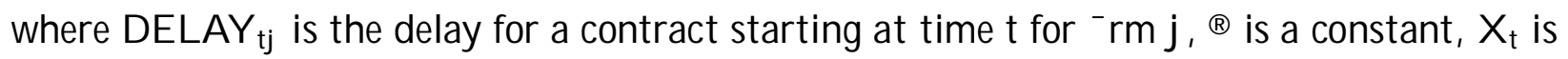
a row vector of time-varying regressors, $Y_{j}$ is a row vector of time-invariant regressors, $W_{t j}$ is a row vector of interactions between $X_{t}$ and $Y_{j}$ variables, and ${ }^{2} t j$ is a disturbance term. The nature of the distribution of ${ }^{2}{ }_{\mathrm{tj}}$ determines the choice of the estimation model, which potentially could be either random-eßects, ${ }^{-}$xed-eßects, or ordinary-least-squares. Statistical tests indicate the superiority of the random-eßects model for our data, which is therefore

\footnotetext{
${ }^{28}$ We also experimented with a variable for days lost due to strikes in the whole economy during the year the previous contract expired, but found no signi ${ }^{-}$cant eßect. We do not use the year of the contract as an explanatory variable, since it might obscure some of the e Rects of the macroeconomic variables. However, when we did try to include the year as a variable, we obtained a signi ${ }^{-}$cant negative estimate of its coe \pm cient, similar estimates of the other coe \pm cients, and a higher $\mathrm{R}^{2}$.

29 Elections may make the government more inclined to grant wage rises to employees in the public sector, which may shorten the negotiations and hence the delays. Since employers in the private sector, at least to some extent, have to match the wages in the public sector, a similar, but possibly smaller, eßect may also be found there. These arguments also imply that elections should have a negative eßect, and that the eßect might be more pronounced in the public sector.
} 
our preferred estimation method.

The random-e ${ }^{\circledR e c t s}$ estimation does not require independence of the ${ }^{2}{ }_{\mathrm{tj}}$ disturbance terms. The method assumes that ${ }^{2}{ }_{t j}=u_{j}+e_{t j}$, where $u_{j}$ and $e_{t j}$ are classical disturbance terms. The disturbance term $u_{j}$ is a ${ }^{-} r m$-speci ${ }^{-} c$ constant that is randomly distributed across - $r m s$, and independent of $e_{t j}$ and time. It is also assumed that $u_{j}$ is uncorrelated with all explanatory variables. ${ }^{30}$ We use the Hausman (1978) test for the null hypothesis that there is no correlation between $u_{j}$ and the observed explanatory variables, a requirement of the random-eßects model (Nerlove 2002, p. 38). Since our panel data set is unbalanced, we use the $\backslash$ feasible" version of generalized-least-squares to estimate the random-eßects model. ${ }^{31}$

In contrast to the random-e ${ }^{\circledR e c t s}$ model, the ${ }^{-}$xed-e eects model assumes that $u_{j}$ is a ${ }^{-} r m$ speci ${ }^{-} \mathrm{c}$ constant, i.e., that the intercept term di ßers among ${ }^{-} \mathrm{rms}$. The simplest estimation of models with ${ }^{-}$xed eßects includes a dummy variable for each ${ }^{-} \mathrm{rm}$ in the sample, which is identical to taking deviations from ${ }^{-} \mathrm{rm}$ means and then estimating an ordinary-least-squares regression. In our case, the random-e Rects model is more satisfactory than the - xed-e®ects model because the latter would exclude all ${ }^{-} \mathrm{rms}$ that have one contract only (and therefore lose much information), and cannot estimate the coe \pm cients of the time-invariant variables. The ${ }^{-}$xed-e ${ }^{-} e c t s$ model also assumes that all ${ }^{-}$rms are represented, which is not satis ${ }^{-}$ed by our sample drawn from a large population of ${ }^{-} \mathrm{rms}$.

The ordinary-least-squares model assumes independence of ${ }^{2} \mathrm{tj}$. This does not appear realistic given that we have repeated observations for the same ${ }^{-} \mathrm{rm}$. B reusch and Pagan (1980) have devised a Lagrangian multiplier test for the ordinary-least-squares model versus the random-e®ects model based on the ordinary-least-squares residuals. The null hypothesis is that the variance of the $u_{j}$ 's vanishes, and rejection of the null hypothesis means that

\footnotetext{
30 If this is not the case, there is an omitted-variables problem and estimates would be biased.

31 The generalized-least-squares estimation weighs the observations in inverse relationship to their variances. Since the variances of the disturbance terms are unknown, a two-stage estimation procedure is used to accomplish the weighing. In the ${ }^{-}$rst stage, ordinary-least-squares is run and the residuals are then used to calculate estimates of the variances. These variance estimates are used in the second stage to obtain the generalized-least-squares parameter estimates.
} 
there is evidence in favor of the error structure of the random eßects model.

In order to test the hypotheses derived from our model, we specify the following timevariant variables $\left(X_{t}\right): z, D\left(z ; z^{\mathbb{d}}\right), 023 / 2,3 / 2, E L E C$, and UNEMP (for simplicity, we omit the time subscripts). The delay is longest for $z=z^{\alpha}$, and is ${ }^{-}$rst increasing and then decreasing in $z$. To estimate the relationship we use a piece-wise linear approximation. Let $D$ be a dummy variable which equals unity if $z>z^{\not}$ and equals zero otherwise. In the regression analysis we enter the variable $D\left(z ; z^{\mathbb{a}}\right)$ in addition to $z$ in order to distinguish between the e eects of $z$ for $z<z^{\not}$ and for $z>z^{\natural}$. The estimate of the nominal uncertainty that impacts the real wage with an immediate renewal is ${ }^{\circ} 23 / \mathbf{z}^{2}$, which is ${ }^{\circ 2}$ times the variance of the shock to the value of money. The estimate of the real uncertainty that impacts the real wage with a delayed renewal is $3 / 2$, which is the variance of the real shock. The variable ELEC is a dummy variables for elections and UNEMP is the unemployment rate. In addition, we specify the cross-section (time-invariant) variable $\left(Y_{j}\right)$ : BRNCH for the ${ }^{-} r m^{\prime}$ s economic branch (for simplicity, we omit the ${ }^{-}$rm subscripts). If the private and public sectors are considered separately, we then have the following estimation equation for each sector:

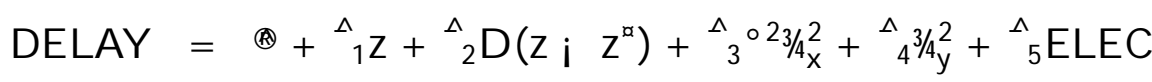

$$
\begin{aligned}
& +\hat{\sigma}_{6} U N E M P+\hat{\oplus B R N C H} \text {. }
\end{aligned}
$$

Our model yields the following predictions:

$2 \hat{1}>0$. This is the positive e eect of $z$ on the delay if $z<z^{\circledR}$.

$2 \hat{1}_{1}+\hat{\imath}_{2}<0$. This is the negative eßect of $z$ on the delay if $z>z^{\not}$.

$2 \hat{3}_{3}>0$. The nominal uncertainty a Rects the delay positively, and a higher gamma is equivalent to larger absolute values of the shocks to the value of money and hence to more nominal uncertainty.

$2 \hat{4}_{4}<0$. The real uncertainty a Rects the delay negatively. 
$2 \hat{5}_{5}<0$. Elections is another indicator of real uncertainty as the economic policy may change if/ when a new government is elected. We therefore expect a negative coe \pm cient.

$2 \hat{6}_{6}<0$. A high unemployment rate is associated with more real uncertainty and therefore expected to have a negative eßect on the delay.

The model provides no a priori predictions about $\underline{\underline{1}}$ for the economic branches, which serve as controls.

To examine the empirical validity of the predictions, we ${ }^{-}$rst run a regression for the length of delay in contract renewal based on the private-sector sample. To check for di ßerential eßects in the private and public sectors, we then run an extended regression of the pooled sample in which we include interaction terms between the public sector and each of the explanatory variables. A signi ${ }^{-}$cant interaction term indicates that the interacted explanatory variable a ßects the delay di ßerently in the two sectors. ${ }^{32}$ The model predicts:

2 The coe \pm cient of the interaction between the public sector and real uncertainty should be positive: real uncertainty shortens the delay in the public sector, but less than in the private sector.

2 The coe \pm cient of the interaction between the public sector and elections should be negative: elections shorten the delay in the public sector more than in the private sector.

2 The coe \pm cient of the interaction between the public sector and the unemployment rate is positive: unemployment shortens the delay in the public sector less than in the private sector.

\footnotetext{
${ }^{32}$ A Iternatively, we could run separate regressions for the two sectors and test for signi ${ }^{-}$cant coe \pm cient di ßerences.
} 


\subsection{The Delay Regressions}

In Table 6, regressions (1) and (2) present the random-erects coe \pm cient estimates of the length-of-delay regressions, using the ${ }^{-} r m$ for the cross-section index ${ }^{33}$ and assuming that $1 / 2=0$. R egression (1) is based on the 1,731 contracts with ${ }^{-}$rms in the private sector only. Regression (2) is based on the pooled sample of 2,103 contracts with - rms in the private and public sectors, and it includes interaction terms between the public sector and each explanatory variable. As the coe \pm cients for the private sector are very similar in regressions (1) and (2), and there is more information in regression (2), we discuss only the results from this regression in detail. ${ }^{34}$

The Hausman test shows that the key assumption in the random-e®ects model, namely that the $u_{j}$ disturbance term is uncorrelated with the explanatory variables, is satis ${ }^{-}$ed. $^{35}$ The $B$ reusch-Pagan test indicates that the random-e ${ }^{\circledR e c t s ~ m o d e l ~ i s ~ p r e f e r a b l e ~ t o ~ t h e ~ o r d i n a r y-~}$ least-squares model. The very large values of $\hat{A}^{2}$ is a sign that a basic assumption of the ordinary-least-squares model, namely that $\operatorname{var}\left(u_{j}\right)=0$, is violated. Accordingly, taken together, the Breusch-Pagan and the Hausman tests show that the random-eßects model is the correct speci ${ }^{-}$cation of the delay function.

The coe \pm cient estimates provide strong support for the theoretical model. They all have the predicted signs and are highly signi ${ }^{-}$cant. This is true for both the private and the public sectors, the only di ßerence being in the magnitude of the eßect of some of the explanatory variables. The uninteracted variables refer to the private sector, and we start by discussing their estimated eßects. ${ }^{36}$

\footnotetext{
33 We have also tried to specify the economic branch for the cross-section index. This leads to basically similar results and generally higher signi ${ }^{-}$cance levels for the coe \pm cients of the key variables.

34 The regressions are based on all 2,103 contracts with zero and positive delay. Using only the 1;890 contracts with positive delay (90\%) leads to similar results. We also estimated the delay regressions using only the $1 ; 850$ contracts with more than a week of delay (88\%). The results are again similar. The same holds true for the likelihood-of-delay estimation.

$35\left(\right.$ Prob $\left.>\hat{A}^{2}\right)=0: 1365$ in regression $(1)$, and $\left(P\right.$ rob $\left.>\hat{A}^{2}\right)=0: 0973$ in regression (2).

${ }^{36}$ For the numerical illustrations we use the means of the macro variables from Table 5 which are based
} 
Recall that $z$ is the ratio between the real wage with delay and what the real wage would be without delay; the delay ${ }^{-}$rst increases and then decreases in $z$, with a peak when the shocks are such that $z=z^{\star}$. The regression results support both the increasing and the decreasing portion of this relationship. This is because $\hat{1}+\hat{2}=i 26: 274$, and an $\hat{A}^{2}$-test yields $\hat{A}^{2}(1)=30: 35$, which is signi ${ }^{-}$cant at less than the 0.001 level. Accordingly, for $z<z^{\not \infty}$ an increase in $z$ by 0.01 causes the delay to be lengthened by 5.998 days, while for $z>z^{\alpha}$ an increase in $z$ by 0.01 causes the delay to be shortened by 26.274 days.

The value of $z$ depends on the realized shocks. A positive nominal shock equal to one standard deviation $(0.0238)$ at the average ${ }^{\circ}(0.4035)$ leads to an increase in the real wage by $0: 0238$ 0:4035 $=0: 96 \%$, or approximately $1 \%$, if the contract renewal is delayed. $\mathrm{A}$ positive real shock equal to one standard deviation (0.0263) leads to an increase in the percapita GDP by $2.63 \%$, and hence to this increase in the real wage if the contract is renewed. Consequently, for $z<z^{\mathfrak{a}}\left(z>z^{\mathfrak{a}}\right)$ a positive one-standard deviation nominal shock increases (decreases) the delay in the average contract by about 6 days (26 days), while a positive one-standard deviation real shock decreases (increases) the delay by about 16 days ( 69 days).

The e Rect of wage indexation on $z$ is the same as if the absolute value of the nominal shock were reduced by a factor of $1_{\mathrm{i}}{ }^{\circ}$. In the face of a positive one-standard-deviation nominal shock, for $z<z^{\not d}$ wage indexation decreases the delay by 599:8 $\propto 0: 0238 \propto 0: 5965=$ 8:5152 days through its e eect on $z$, while for $z>z^{\mathfrak{a}}$ wage indexation increases the delay by $2627: 4 \times 0: 0238 \times 0: 5965=37: 3$ days through its e «ect on $z$.

Since ${ }^{\circ}$ increases with the trend in the value of money, a higher value of the latter is equivalent to an increase in the absolute value of the nominal shock. At a positive onestandard-deviation nominal shock and the average degree of wage indexation, for $z<z^{\text {a }}$ the trend in the value of money on average increases the delay by $599: 8 \propto 0: 0238 \propto(0: 5888 \mathrm{i}$ $0: 4035)=2: 6452$ days through its eßect on $z$, while for $z>z^{\text {d }}$ the trend in the value of money on average decreases the delay by $2627: 4 \propto 0: 0238 \propto(0: 5888 ; 0: 4035)=11: 587$ days

on the pooled sample. The means in the private and public sector are very similar since the contracts in the two sectors are over the same years. 
through its eßect on $z$.

Turning to the nominal and real uncertainty, the regression coe \pm cients show, as predicted by the theory, that the nominal uncertainty increases the delay, while the real uncertainty decreases the delay. At the average value of ${ }^{\circ}$, a doubling of the variance of the nominal shock would increase the delay by 194840 0:4035² 6:8E $\{4=21: 571$ days. Without wage indexation, the delay would have increased by 194840 a6:8E $\{4=132: 49$ days. So wage indexation, through its eßect on ${ }^{\circ}$, reduces the average impact of the variance of the nominal shock to only $16 \%$ of what it would have been in the absence of indexation. A doubling of the variance of the real shock would decrease the delay by $61220 \times 2: 3 E\{4=14: 081$ days.

If the previous contract expires during the year before an election, the delay is shorter by 17.619 days. A $n$ increase in the unemployment rate of one percentage point reduces the delay by 30 days.

Using the Private-Services branch as the reference group, the dummy variables of the economic branches show that the delay is longest for Banking Institutions which has a coe \pm cient of 82.421 . The delay for Banking Institutions is therefore $39 \%$ longer than the average delay of 213.29 days in all economic branches. ${ }^{37}$ Public Services, Manufacturing, and Commerce are not signi ${ }^{-}$cantly di ßerent from Private Services.

The interactions between the public sector and the independent variables indicate the di ßerences between the two sectors. The only signi ${ }^{-}$cant di ßerences are in the e®ect of $z$ on the downward-sloping portion of the relationship between $z$ and the delay; of the variance of the real shock; of elections; and of unemployment. W hile we have no theoretical explanation of why the erect of $z$ on the delay on the downward-sloping portion of the relationship between $z$ and the delay is more negative in the public sector, the latter three di ßerences are as predicted by the theory. In the public sector, the negative relationship

\footnotetext{
${ }^{37}$ Negotiations in Banking Institutions take place among several similar bargaining pairs. The workers therefore have an additional incentive to delay the new contract in order to obtain better information about their own institution's ability to pay by observing the outcomes reached with the other institutions. See Gu and Kuhn (1998).
} 
between real uncertainty and delay, while still negative and signi ${ }^{-}$cant, is weaker than in the private sector. A doubling of the variance of the real shock would decrease the delay by only $(61220 ; 43410) \times 2: 3 E\{4=4: 3263$ days in the public sector versus 14.081 days in the private sector. Upcoming elections reduces the delay in the public sector by an additional 68.930 days, and the e ${ }^{\text {Rect }}$ of elections on delay is more than three times as strong as in the private sector. The signi ${ }^{-}$cant positive coe \pm cient of 18.309 for the interaction term Public sectoraU nemployment cancels the signi ${ }^{-}$cant negative coe \pm cient in the private sector, so that unemployment appears to have no signi ${ }^{-}$cant eßect on the delay in the public sector. ${ }^{38}$

In regressions (1) and (2) the delay is the dependent variable, and the regressions therefore require information about the length of the delay. ${ }^{39}$ We now estimate the likelihood of delay. This approach has the disadvantage that it disregards the available information about the length of delay given that there is a delay, but it is nevertheless instructive and provides a closer link to the theoretical model.

In regression (3) the results of a probit random-e®ects model are presented. The dependent variable is a dummy variable which takes the value of unity if the new contract is delayed and the value of zero if there is no delay. The independent variables are the same as in regression (2), and therefore include public-sector interactions. The hypotheses are identical to those speci ${ }^{-}$ed in section 7.1, except that the dependent variable is now dichotomous. The value of $\hat{A}^{2}$ for the likelihood-ratio test rejects the hypothesis that the panel estimator is the same as the pooled standard probit estimator.

\footnotetext{
${ }^{38} \mathrm{~A} \hat{A}^{2}$-test shows that the sum of the two coe \pm cients is not signi- cantly di ßerent from zero.

39 We have also tried to use relative delay (' delay/duration) as the dependent variable, rather than delay itself. The sign and signi ${ }^{-}$cance of the coe \pm cients are comparable to what is obtained with delay as the dependent variable, except that the coe \pm cient of $z$ is insigni ${ }^{-}$cant. The implied eßects of the variables tend to be smaller. For example, in the pooled sample of contracts in the private and public sectors, at the average value of ${ }^{\circ}$, a doubling of the variance of the nominal shock would increase the relative delay in the private sector by 0:008, which at the average contract duration corresponds to an increase in the delay by 5:0 days. A doubling of the variance of the real shock would decrease the relative delay in the private sector by 0:010, which at the average contract duration corresponds to a decrease in the delay by 6:3 days.
} 
The estimates of the non-interacted variables are generally similar to those in regression (2) in terms of sign and signi ${ }^{-}$cance. The main di ßerence is that the coe \pm cient of $z$ is insigni' cant ( $z=0: 19$ ). Additionally, the likelihood of delay is highest in manufacturing, while there is no signi ${ }^{-}$cant di @erence between the other branches. All interaction terms are insigni ${ }^{-}$cant, implying that the likelihood of delay is similar in the two sectors.

\section{Conclusion}

In many countries, the typical labor contract has $a^{-}$xed duration. Often, however, the ${ }^{-} x e d$ duration is not nearly as sacrosanct as it appears. In reality, there may be lengthy delays before the next contract is concluded, and during these delays the provisions of the I expired" contract remain in force. We present a theoretical model that focuses on macroeconomic factors in explaining delays in contract renewal. In particular, we emphasize the importance of the realized nominal and real shocks, as well as of the levels of nominal and real uncertainty. We show that whether the contract renewal will take place on time or be delayed can be described by a $(s ; S)$ strategy in the ratio of the real wage with a delay to what the real wage would be with a new contract. We also demonstrate that nominal uncertainty tends to favor delay while real uncertainty tends to favor immediate contract renewal.

The model is tested using data from all published Israeli labor contract signed from 1978 to 1995 . The renewal is delayed for $86 \%$ of these contracts, with the average delay being 213 days. The empirical ' ndings strongly support the theory. The coe \pm cient estimates all have the predicted signs and are signi ${ }^{-}$cant. In the private sector, increasing the real wage during a delay by $1 \%$ of the real wage in a new contract would lengthen the average delay by 6 days in the increasing range, and shorten the average delay by 26 days in the decreasing range. A doubling of the level of nominal uncertainty would increase the delay by 22 days, while a doubling of the level of real uncertainty would reduce the delay by 14 days. Since upcoming elections increases the real uncertainty, it also reduces the delay: if the previous contract expires during the year before an election, the delay is reduced by 29 days. 
The full sample of contracts with ${ }^{-}$rms in both the private and public sectors is used to gauge the di ßerent impact of the explanatory variables in the two sectors. The coe \pm cient estimates of the interaction terms with the public sector provides further support for the theoretical model. For example, real uncertainty reduces the delay by less in the public sector while upcoming elections reduce the delay by more than in private sector.

The empirical variables are constructed so that they correspond closely to the variables in the theoretical model, and the period under consideration includes subperiods with extreme di ßerences in in ${ }^{\circ}$ ation and growth rates. This enables us to get robust estimates of the model parameters. In fact, separate regressions for di ßerent subperiods yield coe \pm cient estimates that are similar even though the economic environments are very di ßerent. Needless to say, however, it would be desirable to also test the model with data from other countries. 


\section{R eferences}

Bank of Israel. Bank of I srael A nnual Report. Israel; various issues.

B ank of I srael, R esearch Department. Recent E conomic Developments. Israel; various issues. Bar-Zuri, Roni. IStrikes in Israel during 1983-1992." Economics and Labour 9 (October 1994): 132-155. (Hebrew)

Breusch, T. S. and A. R. Pagan. IThe Lagrange Multiplier Test and Its Applications to Model Speci cation in Econometrics." Review of Economic Studies 47 (J anuary 1980): 239-253.

Caplin, Andrew S. and Spulber, Daniel F. \Menu Costs and the Neutrality of Money." Quarterly J ournal of Economics 102 (November 1987): 703-25.

Card, David. \An Empirical Model of Wage Indexation Provisions in Union Contracts." J ournal of Political Economy 94 (J une 1986): S144-S175.

Central Bureau of Statistics. M onthly Bulletin of Statistics. Israel; various issues.

Central Bureau of Statistics. Statistical A bstract of I srael. Israel; various issues.

Christo- des, Louis N. IThe Impact of Controls on Wage Contract Duration." Economic J ournal 95 (M arch 1985): 161-8.

Christo ${ }^{-}$des, Louis N. and W ilton, David A. IT he Determinants of Contract Length." J ournal of Monetary E conomics 12 (J une 1983): 309-19.

Cohen, Y inon; Haberfeld, Y itchak; M undlak, Guy and Saporta, Y itchak. Unionization Rate and Coverage of Collective Agreements, M inistry of Labour and Social A Rairs, Israel, A ugust, 2001. (Hebrew)

Cramton, Peter C. and Tracy, J oseph S. I Strikes and Holdouts in Wage Bargaining: Theory and Data." American Economic Review 82 (March 1992): 100-21.

Cramton, Peter C. and Tracy, J oseph S. I The Determinants of U.S. Labor Disputes." J ournal of Labor Economics 12 (A pril 1994): 180-209.

Danziger, Leif. \Real Shocks, E \pm cient Risk Sharing, and the Duration of Labor Contracts." Quarterly J ournal of Economics 103 (M ay 1988): 435-40. 
Danziger, Leif. IOn the Prevalence of Labor Contracts with Fixed Duration." American E conomic Review 82 (M arch 1992): 195-206.

Danziger, Leif. IContract Reopeners." J ournal of Labor Economics 13 (J anuary 1995): 62-87.

Dye, Ronald A. IOptimal Length of Labor Contracts." International E conomic Review 26 (February 1985): 251-70.

Ehrenberg, R onald G .; Danziger, Leif, and San, Gee. IC ost-of-Living A djustment Clauses in Union Contracts." In Research in Labor E conomics 6, edited by Ronald G. Ehrenberg, pp. 1-63. Greenwich, CT : J AI Press, 1984.

Fischer, Stanley. ILong-Term Contracts, Rational Expectations, and the Optimal Money Supply Rule." J ournal of Political E conomy 85 (February 1977): 191-205.

Flanagan, Robert J . \M acroeconomic Performance and Collective B argaining: An International Perspective." J ournal of E conomic Literature 37 (September 1999): 1150-75. Gray, J o Anna. IOn Indexation and Contract Length." J ournal of Political E conomy 86 (February 1978): 1150-75.

Gu, Wulong and Kuhn, Peter. \A Theory of Holdouts in Wage Bargaining." American E conomic Review 88 (J une 1998): 428-49.

Hamermesh, Daniel S. IThe Craft of Labormetrics." Industrial and Labor Relations Review 53 (A pril 2000): 363-80.

Harris, Milton and Holmstrom, Bengt. IOn the Duration of A greements." International E conomic Review 28 (J une 1987): 389-405.

Hausman, Jerry. A. ISpeci cation Tests in Econometrics." Econometrica 46 (November, 1978): 1251-71.

Holden, Steinar. IWage Bargaining and Nominal Rigidities." European Economic Review 38 (M ay 1994): 1021-39.

M inistry of Labour and Social A Rairs. Labour, Social A Rairs and National Insurance; M onthly Bulletin of the Ministry of Labour and Social A \&airs. Israel; various issues. 
Murphy, Kevin. J . IDeterminants of Contract Duration in Collective Bargaining Agreements." Industrial and Labor Relations Review 45 (J anuary 1992): 352-65.

Nerlove, Marc L. Essays in Panel Data Econometrics. New York: Cambridge University Press, 2002.

Phelps, Edmund S. and Taylor, J ohn B. IStabilizing Powers of Monetary Policy under Rational Expectations." J ournal of Political Economy 85 (February 1977): 163-90.

Rich, Robert and Tracy, J oseph. IUncertainty and Labor Contract Durations." NBER Working Paper No. 7731, J une 2000.

Taylor, J ohn B. \Staggered Wage Setting in a Macro Model." American Economic Review 69 (M ay 1979): 108-13.

Taylor, J ohn B. \A ggregate Dynamics and Staggered Contracts." J ournal of Political Economy 88 (February 1980): 1-23.

Vroman, Susan B. $\backslash I n^{\circ}$ ation Uncertainty and Contract Duration." Review of Economics and Statistics 71 (November 1989): 677-81.

Wallace, Frederick H., and Blanco, Herminio. IThe E Rects of Real and Nominal Shocks on Union-Firm Contract Duration." J ournal of Monetary Economics 27 (J une 1991): 361-80. 


\section{TABLE 1}

The Bene ${ }^{-} t$ from Delay and the Critical Values of $z$

\begin{tabular}{|c|c|c|c|}
\hline & $B(z)$ & $\mathrm{s}$ & $S$ \\
\hline$z$ & $\vec{z} 0$ as $z \dot{s} z^{\infty}$ & & \\
\hline 1 & $>0$ & $<0$ & $>0$ \\
\hline Nominal Uncertainty & $>0$ & $<0$ & $>0$ \\
\hline$\mu$ & $<0$ & $>0$ & $<0$ \\
\hline$»$ & $z 0$ as $z \geq 1$ & $z 0$ as $s \leqslant 1$ & $z 0$ as $S \gtreqless 1$ \\
\hline Real Uncertainty & $<0$ & $>0$ & $<0$ \\
\hline r & $\sum 0$ as $z \geq 1$ & $\leqslant 0$ as $s_{i} \leq 1$ & $\leq 0$ as $S \geq 1$ \\
\hline
\end{tabular}


TABLE 2

Macro Economic Background Data (Annual)

\begin{tabular}{|c|c|c|c|c|c|}
\hline Year & $\begin{array}{c}\text { Inflation Rate } \\
(\%)\end{array}$ & $\begin{array}{c}\text { Growth Rate } \\
\text { of Per-Capita } \\
\text { GDP (\%) } \\
\end{array}$ & $\begin{array}{l}\text { Real Interest } \\
\text { Rate (\%) }\end{array}$ & $\begin{array}{c}\text { Unemployment } \\
\text { Rate }(\%)\end{array}$ & $\begin{array}{c}\text { Work Days Lost } \\
\text { (due to strikes) per } \\
\text { Thousand Employees } \\
\end{array}$ \\
\hline 1978 & 48.1 & 1.93 & 1.1 & 3.4 & 1054.46 \\
\hline 1979 & 111.4 & 2.05 & -11.4 & 2.9 & 488.50 \\
\hline 1980 & 132.9 & 0.67 & 18.5 & 4.6 & 195.54 \\
\hline 1981 & 101.5 & 2.88 & 34.3 & 5.1 & 684.85 \\
\hline 1982 & 131.5 & -0.46 & 3.8 & 5.0 & 1552.30 \\
\hline 1983 & 190.7 & 0.68 & -3.1 & 4.5 & 818.02 \\
\hline 1984 & 444.9 & 0.15 & 59.8 & 5.9 & 835.15 \\
\hline 1985 & 185.2 & 2.72 & 90.6 & 6.7 & 450.94 \\
\hline 1986 & 19.7 & 2.91 & 33.4 & 7.1 & 339.85 \\
\hline 1987 & 16.1 & 4.61 & 38.6 & 6.1 & 804.29 \\
\hline 1988 & 16.4 & 1.91 & 25.6 & 6.4 & 410.49 \\
\hline 1989 & 20.7 & -0.56 & 11.3 & 8.9 & 185.14 \\
\hline 1990 & 17.6 & 2.82 & 10.2 & 9.6 & 750.88 \\
\hline 1991 & 18.0 & 10.60 & 10.0 & 10.6 & 63.40 \\
\hline 1992 & 9.4 & 3.20 & 11.5 & 11.2 & 234.54 \\
\hline 1993 & 11.2 & 0.68 & 6.2 & 10.0 & 925.52 \\
\hline 1994 & 14.5 & 4.18 & 4.7 & 7.8 & 413.36 \\
\hline 1995 & 8.1 & 4.02 & 13.3 & 6.9 & 126.43 \\
\hline
\end{tabular}

Sources: Bank of Israel: Bank of Israel Annual Report, various issues.

Bank of Israel, Research Department: Recent Economic Developments, various issues.

Central Bureau of Statistics: Monthly Bulletin of Statistics and Statistical Abstract of Israel, various issues.

\section{TABLE 3}

\section{Distribution of Contracts by Sector and by Economic Branch Israeli Labor Market, 1978-1995 (2,103 Contracts)}

\begin{tabular}{|c|c|}
\hline Sector/Economic Branch & Share $(\%)$ \\
\hline $\begin{array}{l}\text { Sector } \\
\begin{array}{ll}-\quad \text { Private } \\
-\quad \text { Public }\end{array}\end{array}$ & $\begin{array}{l}82.31 \\
17.69\end{array}$ \\
\hline $\begin{array}{ll}\text { Economic Branch } \\
\text { - } & \text { Private Services } \\
\text { - } & \text { Public Services } \\
\text { - } & \text { Manufacturing } \\
\text { - } & \text { Commerce } \\
- & \text { Banking Institutions }\end{array}$ & $\begin{array}{r}27.29 \\
9.18 \\
56.97 \\
4.37 \\
2.19\end{array}$ \\
\hline
\end{tabular}

Source: Authors' calculations based on: Ministry of Labour and Social Affairs: Labour, Social Affairs and National Insurance (Monthly Bulletin), various issues. 
TABLE 4

Delays in Contract Renewals and Contract Durations by Sector Israeli Labor Market, 1978-1995

\begin{tabular}{||l||c||c||c||}
\hline \hline & Total & Private Sector & Public Sector \\
\hline \hline Negative delay (\%) & 3.97 & 4.36 & 2.11 \\
\hline No delay (\%) & 10.13 & 11.21 & 5.11 \\
\hline 1-7 days delay (\%) & 1.90 & 1.85 & 2.15 \\
\hline Average delay (days) & 213.29 & 193.79 & 304.02 \\
\hline Relative delay (delay/duration) & $(207.20)$ & $(188.78)$ & $(258.92)$ \\
\hline Average duration (days) & 0.3337 & 0.3151 & 0.4200 \\
\hline Duration of one year (\%) & 649.49 & 628.57 & 746.83 \\
\hline Duration of two years (\%) & $(264.57)$ & $(232.09)$ & $(365.86)$ \\
\hline Duration of more than two years $(\%)$ & 20.73 & 21.43 & 17.47 \\
\hline Duration of more than three years $(\%)$ & 10.27 & 51.70 & 50.81 \\
\hline \hline Sample size & 3.28 & 8.43 & 18.82 \\
\hline \hline
\end{tabular}

Source: Authors' calculations based on:

Ministry of Labour and Social Affairs: Labour, Social Affairs and National Insurance (Monthly Bulletin), various issues.

Note: Figures in parentheses are standard deviations. 
TABLE 5

\section{Characteristics of Regression Variables, Israeli Economy, 1978-1995 (2,103 Contracts)}

\begin{tabular}{|c|c|c|c|c|}
\hline Variable & Mean & $\begin{array}{l}\text { Standard } \\
\text { Deviation }\end{array}$ & $\begin{array}{c}\text { Minimum } \\
\text { Value }\end{array}$ & $\begin{array}{l}\text { Maximum } \\
\text { Value }\end{array}$ \\
\hline Delay (days) & 213.29 & 207.20 & 0 & 1529 \\
\hline $\begin{array}{l}\text { Value of money } \\
\text { - Trend in the value of money } \\
\text { - Nominal shock } \\
\text { - Expected variance of nominal shock }\end{array}$ & $\begin{array}{c}-0.0385 \\
-0.0159 \\
6.8 \mathrm{E}-4 \\
\end{array}$ & $\begin{array}{l}0.0384 \\
0.0238 \\
1.2 \mathrm{E}-3\end{array}$ & $\begin{array}{c}-0.1533 \\
-0.1185 \\
2.9 \mathrm{E}-6 \\
\end{array}$ & $\begin{array}{c}-0.0041 \\
0.1385 \\
7.5 \mathrm{E}-3 \\
\end{array}$ \\
\hline $\begin{array}{ll}\text { GDP } \text { (per-capita) } \\
\text { All economic branches } \\
\text { - } & \text { Trend in GDP } \\
- & \text { Real shock } \\
- & \text { Expected variance of real shock }\end{array}$ & $\begin{array}{l}0.0032 \\
0.0038 \\
2.3 \mathrm{E}-4\end{array}$ & $\begin{array}{c}0.0140 \\
0.0263 \\
5.5 \mathrm{E}-4\end{array}$ & $\begin{array}{c}-0.0224 \\
-0.0306 \\
5.9 \mathrm{E}-9\end{array}$ & $\begin{array}{l}0.0527 \\
0.0780 \\
2.6 \mathrm{E}-3\end{array}$ \\
\hline $\begin{array}{ll}\text { Private services (574 contracts) } \\
-\quad \text { Trend in GDP } \\
-\quad \text { Real shock } \\
-\quad \text { Expected variance of real shock }\end{array}$ & $\begin{array}{l}0.0042 \\
0.0055 \\
2.4 \mathrm{E}-4\end{array}$ & $\begin{array}{l}0.0191 \\
0.0297 \\
6.1 \mathrm{E}-4\end{array}$ & $\begin{array}{c}-0.0177 \\
-0.0306 \\
1.5 \mathrm{E}-6\end{array}$ & $\begin{array}{l}0.0527 \\
0.0780 \\
2.6 \mathrm{E}-3\end{array}$ \\
\hline $\begin{array}{ll}\text { Public services (193 contracts) } \\
-\quad \text { Trend in GDP } \\
-\quad \text { Real shock } \\
-\quad \text { Expected variance of real shock }\end{array}$ & $\begin{array}{l}0.0029 \\
0.0012 \\
6.5 \mathrm{E}-5\end{array}$ & $\begin{array}{l}0.0083 \\
0.0140 \\
1.4 \mathrm{E}-4\end{array}$ & $\begin{array}{c}-0.0096 \\
-0.0191 \\
9.5 \mathrm{E}-8\end{array}$ & $\begin{array}{l}0.0238 \\
0.0339 \\
7.0 \mathrm{E}-4\end{array}$ \\
\hline $\begin{array}{ll}\text { Manufacturing (1,198 contracts) } \\
-\quad \text { Trend in GDP } \\
-\quad \text { Real shock } \\
-\quad \text { Expected variance of real shock }\end{array}$ & $\begin{array}{l}0.0024 \\
0.0048 \\
2.7 \mathrm{E}-4\end{array}$ & $\begin{array}{l}0.0120 \\
0.0278 \\
5.6 \mathrm{E}-4\end{array}$ & $\begin{array}{c}-0.0224 \\
-0.0230 \\
2.9 \mathrm{E}-7\end{array}$ & $\begin{array}{l}0.0252 \\
0.0751 \\
2.4 \mathrm{E}-3\end{array}$ \\
\hline $\begin{array}{ll}\text { Commerce (92 contracts) } \\
-\quad \text { Trend in GDP } \\
-\quad \text { Real shock } \\
-\quad \text { Expected variance of real shock }\end{array}$ & $\begin{array}{l}0.0011 \\
0.0024 \\
1.4 \mathrm{E}-4\end{array}$ & $\begin{array}{l}0.0100 \\
0.0206 \\
1.7 \mathrm{E}-4\end{array}$ & $\begin{array}{c}-0.0095 \\
-0.0265 \\
2.2 \mathrm{E}-6\end{array}$ & $\begin{array}{l}0.0274 \\
0.0510 \\
5.8 \mathrm{E}-4\end{array}$ \\
\hline $\begin{array}{ll}\text { Banking Institutions (46 contracts) } \\
-\quad \text { Trend in GDP } \\
-\quad \text { Real shock } \\
-\quad \text { Expected variance of real shock }\end{array}$ & $\begin{array}{l}0.0021 \\
0.0034 \\
1.2 \mathrm{E}-4\end{array}$ & $\begin{array}{l}0.0124 \\
0.0216 \\
2.4 \mathrm{E}-4\end{array}$ & $\begin{array}{c}-0.0135 \\
-0.0149 \\
5.9 \mathrm{E}-9\end{array}$ & $\begin{array}{l}0.0331 \\
0.0631 \\
8.4 \mathrm{E}-4\end{array}$ \\
\hline Degree of indexation & 0.5888 & 0.1756 & 0.0336 & 1.0000 \\
\hline$\gamma$ & 0.4035 & 0.1775 & 0 & 0.9663 \\
\hline$z$ & 0.9916 & 0.0254 & 0.9031 & 1.0696 \\
\hline Real interest rate & 0.0153 & 0.0129 & -0.0101 & 0.0537 \\
\hline Election years & 0.2240 & - & - & - \\
\hline Unemployment rate & 0.0705 & 0.0232 & 0.0288 & 0.1118 \\
\hline
\end{tabular}

Sources: Authors' calculations based on:

Bank of Israel: Bank of Israel Annual Report, various issues.

Bank of Israel, Research Department: Recent Economic Developments, various issues.

Central Bureau of Statistics: Monthly Bulletin of Statistics and Statistical Abstract of Israel,

various issues.

Ministry of Labour and Social Affairs: Labour, Social Affairs and National Insurance (Monthly

Bulletin), various issues.

Notes:

1. Trend, shock, and real interest rate are per month.

2. The value of $z$ (= the ratio of the real wage with delay to the real wage without delay) is measured in percent. 
TABLE 6

\section{Random-Effects Delay Regressions \\ Israeli Labor Market, 1978-1995}

\begin{tabular}{|c|c|c|c|}
\hline & $\begin{array}{l}\text { (1) } \\
\text { Length-of-Delay } \\
\text { in Private Sector }\end{array}$ & $\begin{array}{c}\text { (2) } \\
\text { Length-of-Delay } \\
\text { in Private and Public Sector, } \\
\text { With Public-Sector } \\
\text { Interactions } \\
\end{array}$ & $\begin{array}{c}\text { (3) } \\
\text { Likelihood-of-Delay } \\
\text { in Private and Public Sector, } \\
\text { With Public-Sector } \\
\text { Interactions } \\
\end{array}$ \\
\hline Independent variables & Coefficient $(z-$ value $)$ & Coefficient (z-value) & Coefficient (z-value) \\
\hline$z$ & $5.471(2.66)$ & $5.998(2.60)$ & $-0.010(0.19)$ \\
\hline$D\left(z-z^{*}\right)$ & $-30.910(5.79)$ & $-32.272(5.35)$ & $-0.362(2.85)$ \\
\hline$\gamma^{2} *$ exp. variance of nominal shock & $19.031(6.07)$ & $19.484(5.51)$ & $0.263(2.88)$ \\
\hline Exp. variance of real shock & $-6.029(7.85)$ & $-6.122(7.11)$ & $-0.065(4.01)$ \\
\hline Elections & $-28.685(2.87)$ & $-30.003(2.67)$ & $-0.287(1.22)$ \\
\hline Unemployment rate $(\%)$ & $-16.827(7.73)$ & $-17.619(7.28)$ & $-0.230(4.39)$ \\
\hline \multicolumn{4}{|l|}{ Economic Branch } \\
\hline Public Services & $-85.512(1.92)$ & $-82.821(1.69)$ & $1.080(0.81)$ \\
\hline Manufacturing & $-21.460(1.95)$ & $-19.477(1.45)$ & $0.777(2.97)$ \\
\hline Commerce & $-15.504(0.62)$ & $-8.514(0.32)$ & $0.641(1.04)$ \\
\hline Banking Institutions & $60.518(1.38)$ & $82.421(1.91)$ & $1.322(1.29)$ \\
\hline Public Sector & - & $-12.301(0.36)$ & $-1.625(0.09)$ \\
\hline Public Sector $* z$ & - & $-2.793(0.49)$ & $0.026(0.14)$ \\
\hline Public Sector $* D\left(z-z^{*}\right)$ & - & $-32.311(1.97)$ & $-0.489(1.31)$ \\
\hline $\begin{array}{l}\text { Public Sector } * \\
\gamma^{2} * \text { exp. variance of nominal shock }\end{array}$ & - & $14.540(1.49)$ & $0.092(0.24)$ \\
\hline $\begin{array}{l}\text { Public Sector } * \\
\text { Exp. variance of real shock }\end{array}$ & - & $4.341(1.94)$ & $-0.023(0.47)$ \\
\hline Public Sector $*$ Elections & - & $-68.930(2.33)$ & $0.752(0.68)$ \\
\hline Public Sector $*$ Unemployment rate $(\%)$ & - & $18.309(3.59)$ & $0.104(0.61)$ \\
\hline Constant & $-193.222(0.98)$ & $-241.018(1.09)$ & $5.254(0.98)$ \\
\hline$R^{2}$ & 0.0958 & 0.1312 & \\
\hline$\chi^{2}$ for Hausman test & 14.88 & 28.54 & \\
\hline$\chi^{2}$ for Breusch-Pagan test & 268.97 & 203.35 & \\
\hline$\chi^{2}$ for likelihood-ratio test & & & 76.47 \\
\hline Sample size & 1,731 & 2,103 & 2,103 \\
\hline
\end{tabular}

\section{Notes:}

1. STATA 7.0 is used for estimation.

2. The values of $z$ and of $D\left(z-z^{*}\right)$ are measured in percent. The expected variances of the nominal and real shocks are measured in (percent $)^{2}$.

3. The firm is used as the cross-section identifier.

4. The reference group for Economic Branch is: Private Services.

5. The null hypothesis of the Hausman test is that there is no correlation between $u_{j}$ and the explanatory variables, in which case the random-effects specification is correct. The null hypothesis of the Breusch-Pagan test is that $\operatorname{var}\left(u_{j}\right)=0$ in which case ordinary-least-squares estimates would be better than random-effects estimates. The null hypothesis of the likelihood-ratio test is that the panel estimator is the same as the pooled standard probit estimator.

6. Regressions (2) and (3) also include interactions between the public sector and the economic branches. These are not reported as none of their coefficients is significant. 
Chart 1

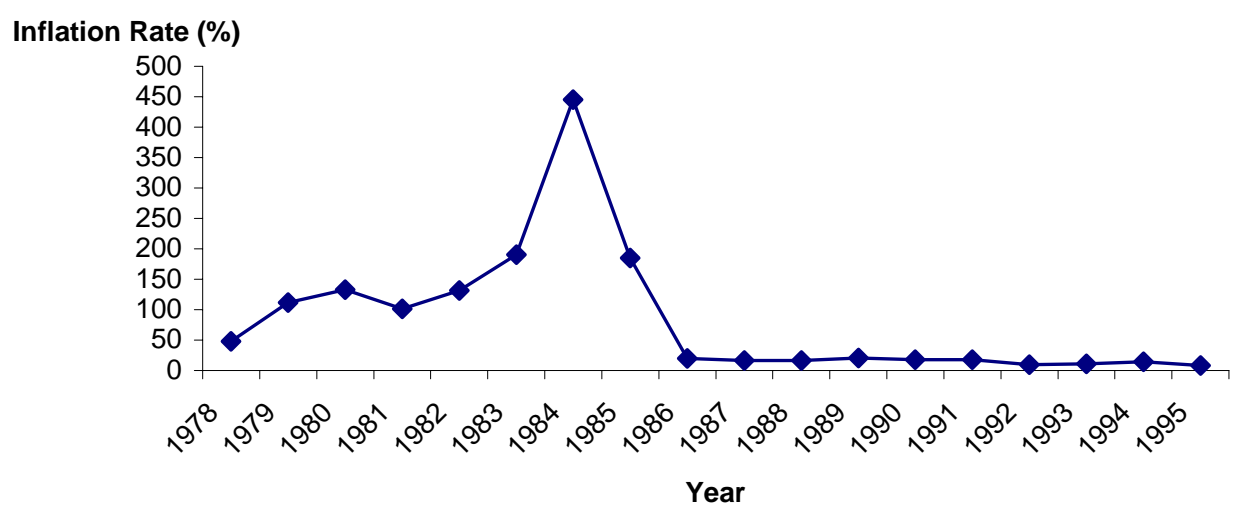


Chart 2

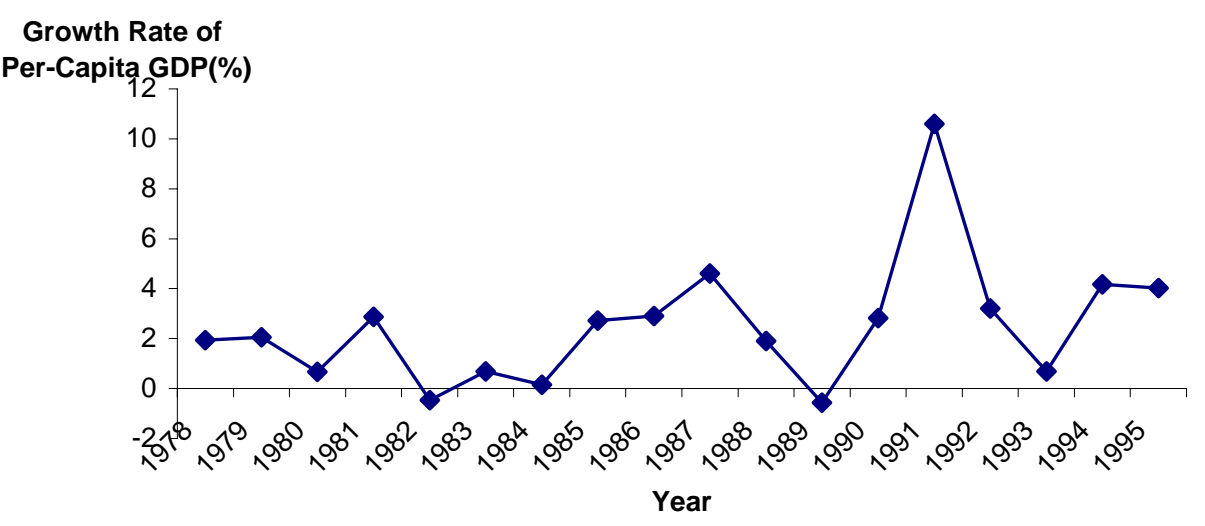




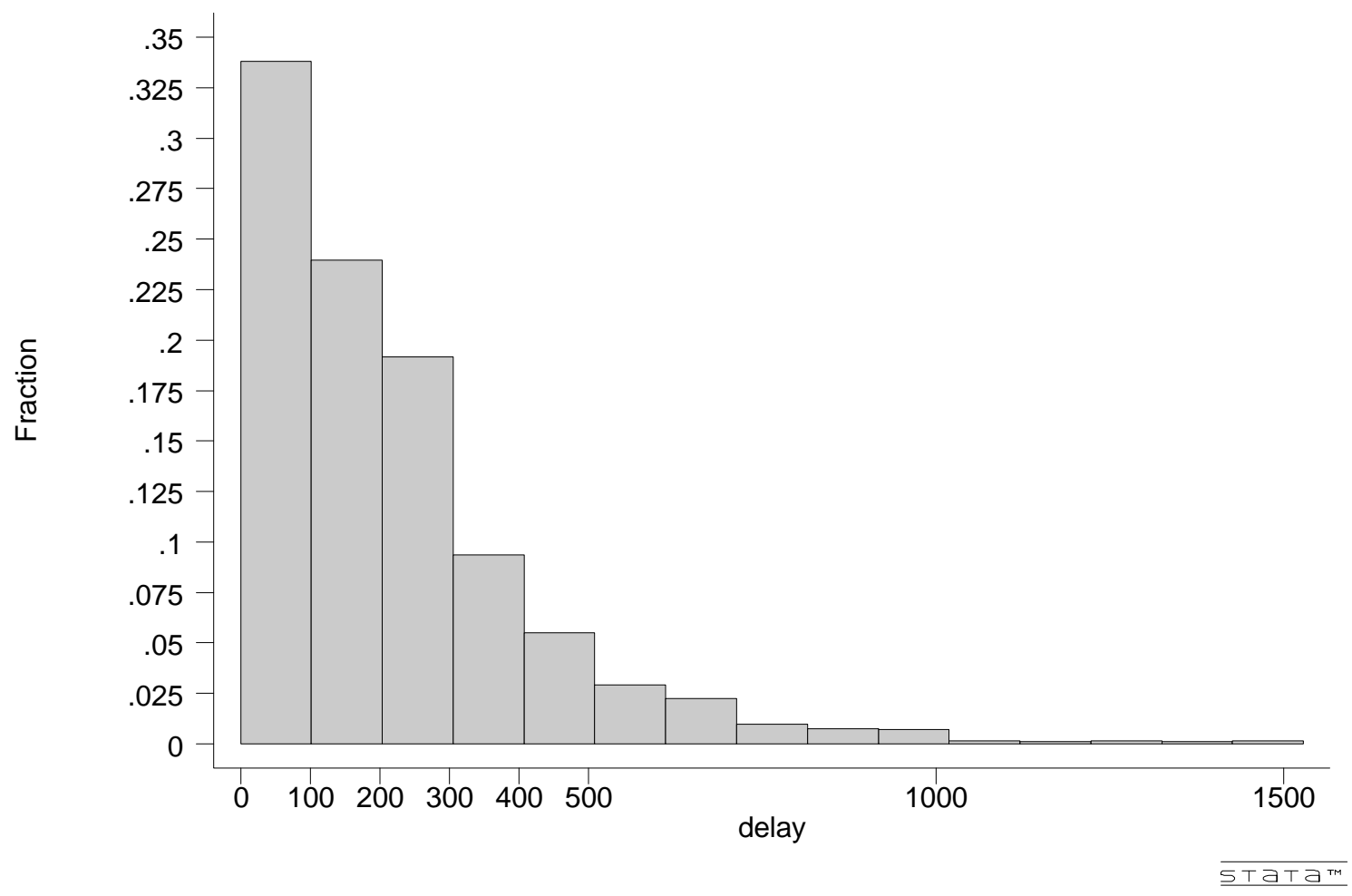




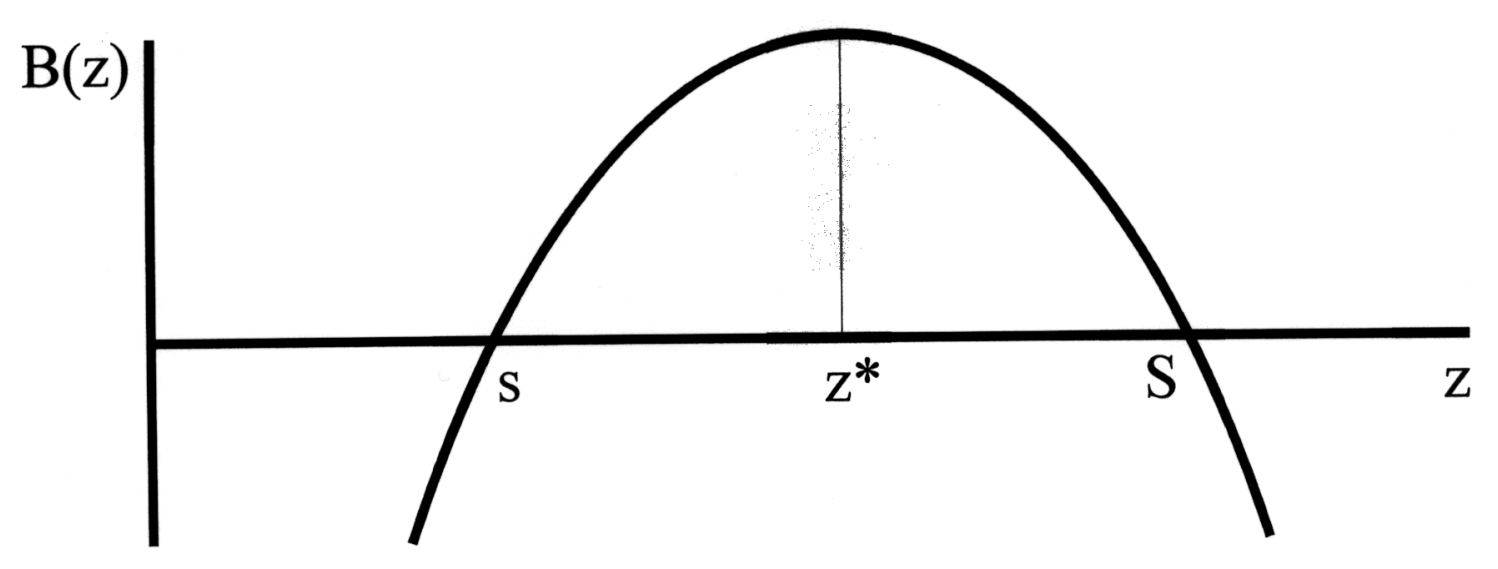

F GURE 


\section{IZA Discussion Papers}

\begin{tabular}{|c|c|c|c|c|}
\hline No. & Author(s) & Title & Area & Date \\
\hline 694 & E. S. Prasad & $\begin{array}{l}\text { What Determines the Reservation Wages of } \\
\text { Unemployed Workers? New Evidence from } \\
\text { German Micro Data }\end{array}$ & 3 & $01 / 03$ \\
\hline 695 & $\begin{array}{l}\text { S. Alan } \\
\text { T. F. Crossley } \\
\text { P. Grootendorst } \\
\text { M. R. Veall }\end{array}$ & $\begin{array}{l}\text { Out-of-Pocket Prescription Drug Expenditures } \\
\text { and Public Prescription Drug Programs }\end{array}$ & 3 & $01 / 03$ \\
\hline 696 & R. Schettkat & $\begin{array}{l}\text { Institutions in the Economic Fitness Landscape: } \\
\text { What Impact Do Welfare State Institutions Have } \\
\text { on Economic Performance? }\end{array}$ & 3 & $01 / 03$ \\
\hline 697 & R. Schettkat & $\begin{array}{l}\text { Differences in US-German Time-Allocation: } \\
\text { Why Do Americans Work Longer Hours than } \\
\text { Germans? }\end{array}$ & 5 & $01 / 03$ \\
\hline 698 & $\begin{array}{l}\text { T. M. Andersen } \\
\text { J. R. Skaksen }\end{array}$ & $\begin{array}{l}\text { Product Market Integration, Comparative } \\
\text { Advantages and Labour Market Performance }\end{array}$ & 2 & $01 / 03$ \\
\hline 699 & $\begin{array}{l}\text { D. Margolis } \\
\text { V. Simonnet }\end{array}$ & $\begin{array}{l}\text { Educational Track, Networks and Labor Market } \\
\text { Outcomes }\end{array}$ & 2 & $01 / 03$ \\
\hline 700 & T. K. Bauer & $\begin{array}{l}\text { Flexible Workplace Practices and Labor } \\
\text { Productivity }\end{array}$ & 1 & $01 / 03$ \\
\hline 701 & $\begin{array}{l}\text { L. Goerke } \\
\text { J. B. Madsen }\end{array}$ & $\begin{array}{l}\text { Earnings-Related Unemployment Benefits in a } \\
\text { Unionised Economy }\end{array}$ & 3 & $01 / 03$ \\
\hline 702 & $\begin{array}{l}\text { M. Ayhan Kose } \\
\text { E. S. Prasad } \\
\text { M. E. Terrones }\end{array}$ & $\begin{array}{l}\text { How Does Globalization Affect the } \\
\text { Synchronization of Business Cycles? }\end{array}$ & 2 & $01 / 03$ \\
\hline 703 & $\begin{array}{l}\text { W. C. Horrace } \\
\text { R. L. Oaxaca }\end{array}$ & $\begin{array}{l}\text { New Wine in Old Bottles: A Sequential } \\
\text { Estimation Technique for the LPM }\end{array}$ & 6 & $01 / 03$ \\
\hline 704 & $\begin{array}{l}\text { M. Ransom } \\
\text { R. L. Oaxaca }\end{array}$ & Intrafirm Mobility and Sex Differences in Pay & 1 & $01 / 03$ \\
\hline 705 & $\begin{array}{l}\text { G. Brunello } \\
\text { D. Checchi }\end{array}$ & School Quality and Family Background in Italy & 2 & $01 / 03$ \\
\hline 706 & $\begin{array}{l}\text { S. Girma } \\
\text { H. Görg }\end{array}$ & $\begin{array}{l}\text { Blessing or Curse? Domestic Plants' Survival } \\
\text { and Employment Prospects after Foreign } \\
\text { Acquisitions }\end{array}$ & 1 & $01 / 03$ \\
\hline 707 & $\begin{array}{l}\text { C. Schnabel } \\
\text { J. Wagner }\end{array}$ & $\begin{array}{l}\text { Trade Union Membership in Eastern and } \\
\text { Western Germany: Convergence or } \\
\text { Divergence? }\end{array}$ & 3 & $01 / 03$ \\
\hline 708 & $\begin{array}{l}\text { C. Schnabel } \\
\text { J. Wagner }\end{array}$ & $\begin{array}{l}\text { Determinants of Trade Union Membership in } \\
\text { Western Germany: Evidence from Micro Data, } \\
1980-2000\end{array}$ & 3 & $01 / 03$ \\
\hline 709 & $\begin{array}{l}\text { L. Danziger } \\
\text { S. Neuman }\end{array}$ & $\begin{array}{l}\text { Delays in Renewal of Labor Contracts: Theory } \\
\text { and Evidence }\end{array}$ & 1 & $02 / 03$ \\
\hline
\end{tabular}

An updated list of IZA Discussion Papers is available on the center's homepage www.iza.org. 